\title{
Devils Hole, Nevada-A Photographic Story of a Restricted Subaqueous Environment
}

Open-File Report 2017-1058 



\section{Devils Hole, Nevada-A Photographic Story of a Restricted Subaqueous Environment}

By Ray J. Hoffman

Open-File Report 2017-1058 


\title{
U.S. Department of the Interior \\ RYAN K. ZINKE, Secretary
}

\section{U.S. Geological Survey William H. Werkheiser, Acting Director}

\author{
U.S. Geological Survey, Reston, Virginia: 2017
}

For more information on the USGS - the Federal source for science about the Earth, its natural and living resources, natural hazards, and the environment-visit https://www.usgs.gov or call 1-888-ASK-USGS.

For an overview of USGS information products, including maps, imagery, and publications, visit https://store.usgs.gov.

Any use of trade, firm, or product names is for descriptive purposes only and does not imply endorsement by the U.S. Government.

\footnotetext{
Suggested citation:

Hoffman, R.J., 2017, Devils Hole, Nevada—A photographic story of a restricted subaqueous environment: U.S. Geological Survey Open-File Report 2017-1058, 34 p., https://doi.org/10.3133/ofr20171058.

ISSN 2331-1258 (online)
} 


\section{Contents}

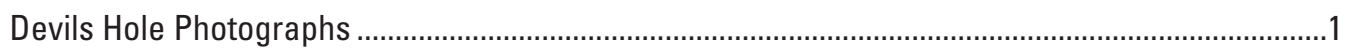

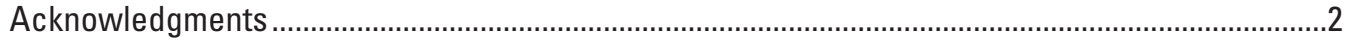

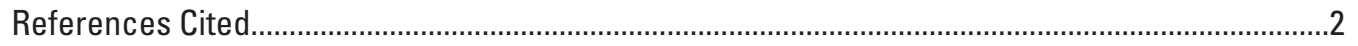

\section{Figures}

\section{1-31 Photographs showing}

1. Interpretive sign describing Devils Hole, Death Valley National Park, Nevada ................4

2. Naturally formed opening of Devils Hole, Death Valley National Park, Nevada. This naturally formed opening to the regional aquifer provides the only known natural habitat for the endangered Devils Hole pupfish.................................................................5

3. View looking northeast at the entrance to Devils Hole, Death Valley National Park, Nevada .

4. Schematic diagram portraying a southwest-northeast cross section of Devils Hole, Death Valley National Park, Nevada

5. A fish-eye view of Devils Hole, Death Valley National Park, Nevada................................8

6. View looking up from Anvil Rock, Devils Hole, Death Valley National Park, Nevada .......9

7. Battery Rock, Devils Hole, Death Valley National Park, Nevada.......................................10

8. View looking down from Battery Rock, Devils Hole, Death Valley National Park, Nevada ......................................................................................................................... 11

9. Footwall in the main chamber, Devils Hole, Death Valley National Park, Nevada ..........12

10. U.S. Geological Survey research diver near Anvil Rock, Devils Hole, Death Valley National Park, Nevada.

11. Exposed cross section of mammillary calcite and U.S. Geological Survey research diver in the main chamber of Devils Hole, Death Valley National Park, Nevada.............14

12. U.S. Geological Survey research diver at entrance to narrow passageway in the main chamber of Devils Hole, Death Valley National Park, Nevada.

13. U.S. Geological Survey research diver in a passageway, Devils Hole, Death Valley National Park, Nevada........................................................................................................16

14. Mammillary calcite, Browns Room, Devils Hole, Death Valley National Park,

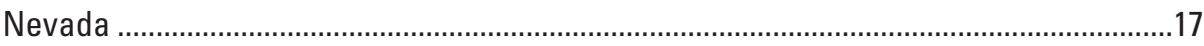

15. Browns Room and pool, Devils Hole, Death Valley National Park, Nevada .....................18

16. Breakdown debris near the pool in Browns Room, Devils Hole, Death Valley National Park, Nevada...

17. Folia in the northeast corner of the pool in Browns Room, Devils Hole, Death Valley National Park, Nevada..

18. Folia in pool in Browns Room, Devils Hole, Death Valley National Park, Nevada ...........21

19. Folia and popcorn at the northeast corner of the pool in Browns Room, Devils Hole, Death Valley National Park, Nevad.

20. Dive light by the west wall of Browns Room, Devils Hole, Death Valley National Park, Nevada.

21. Folia and mammillary calcite below water surface in the southwest corner of Browns Room, Devils Hole, Death Valley National Park, Nevada 
22. Folia just above the water surface in Browns Room, Devils Hole, Death Valley National Park, Nevada.

23. Pool in the northwest corner of Browns Room, Devils Hole, Death Valley National Park, Nevada.

24. West wall in Browns Room, Devils Hole, Death Valley National Park, Nevada...............27

25. U.S. Geological Survey research diver in the pool of Browns Room, Devils Hole, Death Valley National Park, Nevada ..............................................................................28

26. Water surface of Leinhaupel's Pool, Devils Hole, Death Valley National Park, Nevada

27. U.S. Geological Survey research diver coring in the main chamber, Devils Hole, Death Valley National Park, Nevada 30

28. Coring apparatus, Devils Hole, Death Valley National Park, Nevada ...............................31

29. A 4-inch-diameter core hole, Devils Hole, Death Valley National Park, Nevada ............32

30. Setup used to obtain mammillary calcite core, Devils Hole, Death Valley National Park, Nevada

31. U.S. Geological Survey research diver holding a core of mammillary calcite, Devils Hole, Death Valley National Park, Nevada.

\section{Conversion Factors}

U.S. customary units to International System of Units

\begin{tabular}{|c|c|c|}
\hline Multiply & By & To obtain \\
\hline \multicolumn{3}{|c|}{ Length } \\
\hline inch (in.) & 2.54 & centimeter $(\mathrm{cm})$ \\
\hline inch (in.) & 25.4 & millimeter $(\mathrm{mm})$ \\
\hline foot $(\mathrm{ft})$ & 0.3048 & meter $(\mathrm{m})$ \\
\hline
\end{tabular}

Temperature in degrees Celsius $\left({ }^{\circ} \mathrm{C}\right)$ may be converted to degrees Fahrenheit $\left({ }^{\circ} \mathrm{F}\right)$ as follows:

$$
{ }^{\circ} \mathrm{F}=\left(1.8 \times{ }^{\circ} \mathrm{C}\right)+32 \text {. }
$$

Temperature in degrees Fahrenheit $\left({ }^{\circ} \mathrm{F}\right)$ may be converted to degrees Celsius $\left({ }^{\circ} \mathrm{C}\right)$ as follows:

$$
{ }^{\circ} \mathrm{C}=\left({ }^{\circ} \mathrm{F}-32\right) / 1.8 .
$$

\section{Abbreviations}

PVC polyvinyl chloride

USGS U.S. Geological Survey 


\title{
Devils Hole, Nevada-A Photographic Story of a Restricted Subaqueous Environment
}

\author{
By Ray J. Hoffman ${ }^{1}$
}

\section{Devils Hole Photographs}

Devils Hole is an internationally known cave in south-central Nevada, primarily known for the endangered pupfish Cyprinodon diabolis, which dwell there, and for its calcite deposits that have yielded a 570,000-year record of Great Basin paleoclimate (Landwehr and Winograd, 2012). This report presents selected photographic images taken by the author during U.S. Geological Survey (USGS) scuba explorations of the cavern between 1984 and 1993 in support of the paleoclimate and geochemical studies at this site. Diving activities between 1950 and 1986 were discussed by Hoffman (1988). The principal research dive team included Alan C. Riggs (U.S. Geological Survey, retired), Peter T. Kolesar (Professor Emeritus, Utah State University, Logan, Utah), and Ray J. Hoffman (U.S. Geological Survey, retired).

The geology and hydrology of the Devils Hole area has been discussed by Winograd and Thordarson (1975), Dudley and Larson (1976), Carr (1988), and Riggs and others (1994). The unaltered suite of photographs was prepared by the USGS dive team several years ago as an aid to assist nondiving scientists with a visual perspective of the environment where a variety of speleothems (mammillary calcite [vein calcite], flowstone, and folia) were collected to be subsequently analyzed and eventually described in the geologic literature, such as the following:

Winograd and others, 1988;

Winograd and Szabo, 1988;

Riggs, 1991;

Winograd, 1991;

Ludwig and others 1992;

Winograd and others, 1992;

Winograd and Landwehr, 1993;

Coplen and others, 1994;

Riggs and others, 1994;

Szabo and others, 1994;

Winograd and others, 1996;

Landwehr and others, 1997;

Winograd and others, 1997;

Winograd and others, 1998;

Plummer and others, 2000;

Révész and Landwehr, 2002;

Winograd, 2002;

Kolesar, 2004;

Kolesar and Riggs, 2004;

Winograd and others, 2006;

Coplen, 2007;

Landwehr and others, 2011; and

Landwehr and Winograd, 2012.

Not only is Devils Hole a restricted habitat for the endangered Devils Hole pupfish (Cyprinodon diabolis), it is also a legally restricted environment to human traffic. Hence, these photographs (figs. 1-3, 5-31) and their captions may give the interested scientist and nonscientist alike an appreciation of a natural subaqueous environment where few people are privileged to explore.

The photographs shown in figures in this report were taken by Ray J. Hoffman between 1985 and 1987 using a Nikonos V 35-millimeter underwater camera with an attached Nikonos SB-102 speedlight having through-the-lens automatic flash exposure control. The camera lens was $\mathrm{f} / 2.5$, and the film used was ISO 400 color print. The locations of many of the figures in this report are referenced to letters A through $\mathrm{J}$ in figure 4. Figures 13 through 26 were taken in an underground environment completely devoid of natural light.

${ }^{1}$ U.S. Geological Survey, retired. 


\section{Acknowledgments}

This work at Devils Hole, Nevada, could not have been done without the outstanding leadership of Isaac J. Winograd (U.S. Geological Survey, emeritus), who provided several reviews of the document. Jacqueline Benefield (U.S. Geological Survey) provided a helpful review that improved this report. I thank Alan C. Riggs (U.S. Geological Survey, retired) and Peter T. Kolesar (Utah State University, Logan, Utah, retired) for reviewing the figure captions herein. The preparation of this document by Tyler B. Coplen (U.S. Geological Survey) is appreciated. The support of the U.S. Geological Survey National Research Program made this report possible.

\section{References Cited}

Carr, W.J., 1988, Geology of the Devils Hole area, Nevada: U.S. Geological Survey Open-File Report 87-560, 34 p., 3 pls., accessed November 18, 2016, at https://pubs.er.usgs.gov/publication/ofr87560.

Coplen, T.B., 2007, Calibration of the calcite-water oxygen-isotope geothermometer at Devils Hole, Nevada, a natural laboratory: Geochimica et Cosmochimica Acta, v. 71, no. 16, p. 3948-3957. [Also available at http://dx.doi.org/10.1016/j.gca.2007.05.028.]

Coplen, T.B., Winograd, I.J., Landwehr, J.M., and Riggs, A.C., 1994, 500,000-year stable carbon isotopic record from Devils Hole, Nevada: Science, v. 263, no. 5145, p. 361-365. [Also available at https://doi.org/10.1126/science.263.5145.361.]

Dudley, W.W., Jr., and Larson, J.D., 1976, Effect of irrigation pumping on desert pupfish habitats in Ash Meadows, Nye County, Nevada: U.S. Geological Survey Professional Paper 927, 52 p. [Also available at https://pubs.er.usgs.gov/publication/pp927.]

Hoffman, R.J., 1988, Chronology of diving activities and underground surveys in Devils Hole and Devils Hole Cave, Nye County, Nevada, 1950-86: U.S. Geological Survey Open-File Report 88-93, 12 p. [Also available at https://pubs.er.usgs.gov/publication/ofr8893.]

Kolesar, P.T., 2004, New Devils Hole paleoclimate record-Preliminary appraisal of a new paleoclimate record from Devils Hole, Nevada: Northeastern Geology and Environmental Sciences, v. 26, nos. 1-2, p. 49-56.

Kolesar, P.T., and Riggs, A.C., 2004, Influence of depositional environment on Devils Hole calcite morphology and petrology, in Sasowsky, I.D., and Mylroie, John, eds., Studies of cave sediments-Physical and chemical records of paleoclimate: New York, Kluwer Academic/Plenum Publishers, p. 227-241. [Also available at https://doi.org/10.1007/978-1-4419-9118-8_12.]

Landwehr, J.M., Coplen, T.B., Ludwig, K.R., Winograd, I.J., and Riggs, A.C., 1997, Data for Devils Hole core DH-11: U.S. Geological Survey Open-File Report 97-792, 8 p., accessed November 18, 2016, at http:/pubs.usgs.gov/of/1997/ofr97-792/.

Landwehr, J.M., and Winograd, I.J., 2012, Devils Hole, Nevada—A primer: U.S. Geological Survey Fact Sheet 2012-3021, 6 p., accessed November 18, 2016, at http://pubs.usgs.gov/fs/2012/3021.

Landwehr, J.M., Sharp, W.D., Coplen, T.B., Ludwig, K.R., and Winograd, I.J., 2011, The chronology for the $\delta^{18}$ O record from Devils Hole, Nevada, extended into the mid-Holocene: U.S. Geological Survey Open-File Report 2011-1082, 5 p., accessed November 18, 2016, at http://pubs.usgs.gov/of/2011/1082/.

Ludwig, K.R., Simmons, K.R., Szabo, B.J., Winograd, I.J., Landwehr, J.M., Riggs, A.C., and Hoffman, R.J., 1992, Massspectrometric ${ }^{230} \mathrm{Th}^{-234} \mathrm{U}-{ }^{238} \mathrm{U}$ dating of the Devils Hole calcite vein: Science, v. 258, no. 5080, p. 284-287. [Also available at https://doi.org/10.1126/science.258.5080.284.]

Plummer, L.N., Busenberg, E., and Riggs, A.C., 2000, In-situ growth of calcite at Devils Hole, Nevada — Comparison of field and laboratory rates to a 500,000 year record of near-equilibrium calcite growth: Aquatic Geochemistry, v. 6, no. 2, p. 257-274. [Also available at https://doi.org/10.1023/A:1009627710476.]

Révész, K.M., and Landwehr, J.M., 2002, $\delta^{13} \mathrm{C}$ and $\delta^{18} \mathrm{O}$ isotopic composition of $\mathrm{CaCO}_{3}$ measured by continuous flow isotope ratio mass spectrometry-Statistical evaluation and verification by application to Devils Hole core DH-11 calcite: Rapid Communications in Mass Spectrometry, v. 16, no. 2, p. 2102-2114. [Also available at https://doi.org/10.1002/rcm.833.] 
Riggs, A.C., 1991, Geohydrologic evidence for the development of Devils Hole, southern Nevada, as an aquatic environment: Proceedings of the Desert Fishes Council, v. XX, p. 47-48.

Riggs, A.C., Carr, W.J., Kolesar, P.T., and Hoffman, R.J., 1994, Tectonic speleogenesis of Devils Hole, Nevada, and implications for hydrogeology and the development of long, continuous paleoenvironmental records: Quaternary Research, v. 42, no. 3 , p. 241-254. [Also available at https://doi.org/10.1006/qres.1994.1075.]

Szabo, B.J., Kolesar, P.T., Riggs, A.C., Winograd, I.J., and Ludwig, K.R., 1994, Paleoclimatic inferences from a 120,000yr calcite record of water-table fluctuation in Browns Room of Devils Hole, Nevada: Quaternary Research, v. 41, no. 1, p. 59-69. [Also available at https://doi.org/10.1006/qres.1994.1007.]

U.S. Geological Survey, 2005, SW-NE section of Devils Hole, Death Valley National Park, Nevada: U.S. Geological Survey image, accessed November 16, 2016, at https://www.sciencebase.gov/catalog/item/58053885e4b0824b2d1c1e10.

Winograd, I.J., 1991, Time of isolation of Cyprinodon diabolis in Devils Hole-Geologic evidence: Proceedings of the Desert Fishes Council, v. XX, p. 49-50.

Winograd, I.J., 2002, The California current, Devils Hole, and Pleistocene climate: Science, v. 296, no. 5565, p. 7a-7b, accessed November 18, 2016, at https://doi.org/10.1126/science.296.5565.7a.

Winograd, I.J., Coplen, T.B., Landwehr, J.M., Riggs, A.C., Ludwig, K.R., Szabo, B.J., Kolesar, P.T., and Revesz, K.M., 1992, Continuous 500,000-year climate record from vein calcite in Devils Hole, Nevada: Science, v. 258, no. 5080, p. 255-260. [Also available at https://doi.org/10.1126/science.258.5080.255.]

Winograd, I.J., Coplen, T.B., Ludwig, K.R., Landwehr, J.M., and Riggs, A.C., 1996, High resolution $\delta^{18} \mathrm{O}$ record from Devils Hole, Nevada, for the period 80 to 19 ka: EOS, v. 77, no. 17, supp., p. S169.

Winograd, I.J., Coplen, T.B., Szabo, B.J., and Riggs, A.C., 1988, A 250,000-year climate record from Great Basin vein calcite-Implications for Milankovitch theory: Science, v. 242, no. 4883, p. 1275-1280. [Also available at https://doi.org/10.1126/science.242.4883.1275.]

Winograd, I.J., and Landwehr, J.M., 1993, A response to "Milankovitch theory viewed from Devils Hole" by J. Imbrie, A.C. Mix, and D.G. Martinson: U.S. Geological Survey Open-File Report 93-357, 9 p., accessed November 18, 2016, at http://pubs.usgs.gov/of/1993/0357/report.pdf.

Winograd, I.J., Landwehr, J.M., Coplen, T.B., Sharp, W.D., Riggs, A.C., Ludwig, K.R., and Kolesar, P.T., 2006, Devils Hole, Nevada, $\delta^{18} \mathrm{O}$ record extended to the mid-Holocene: Quaternary Research, v. 66, no. 2, p. 202-212. [Also available at http://dx.doi.org/10.1016/j.yqres.2006.06.003.]

Winograd, I.J., Landwehr, J.M., Ludwig, K.R., Coplen, T.B., and Riggs, A.C, 1997, Duration and structure of the past four interglaciations: Quaternary Research, v. 48, no. 2, p. 141-154. [Also available at https://doi.org/10.1006/qres.1997.1918.]

Winograd, I.J., Riggs, A.C., and Coplen, T.B., 1998, The relative contributions of summer and cool-season precipitation to groundwater recharge, Spring Mountains, Nevada, USA: Hydrogeology Journal, v. 6, no. 1, p. 77-93. [Also available at https://doi.org/10.1007/s100400050135.]

Winograd, I.J., and Szabo, B.J., 1988, Water-table decline in the south-central Great Basin during the Quaternary-Implications for toxic waste disposal, in Carr, M.D., and Yount, J.C., eds., Geologic and hydrologic investigations of a potential nuclear waste disposal site at Yucca Mountain, southern Nevada: U.S. Geological Survey Bulletin 1790, p. 147-152, accessed November 18, 2016, at http://pubs.usgs.gov/bul/1790/report.pdf.

Winograd, I.J., and Thordarson, William, 1975, Hydrogeologic and hydrochemical framework, south-central Great Basin, Nevada-California, with special reference to the Nevada Test Site: U.S. Geological Survey Professional Paper 712-C, 126 p., 3 pls., accessed November 18, 2016, at http://pubs.usgs.gov/pp/0712c/report.pdf. 


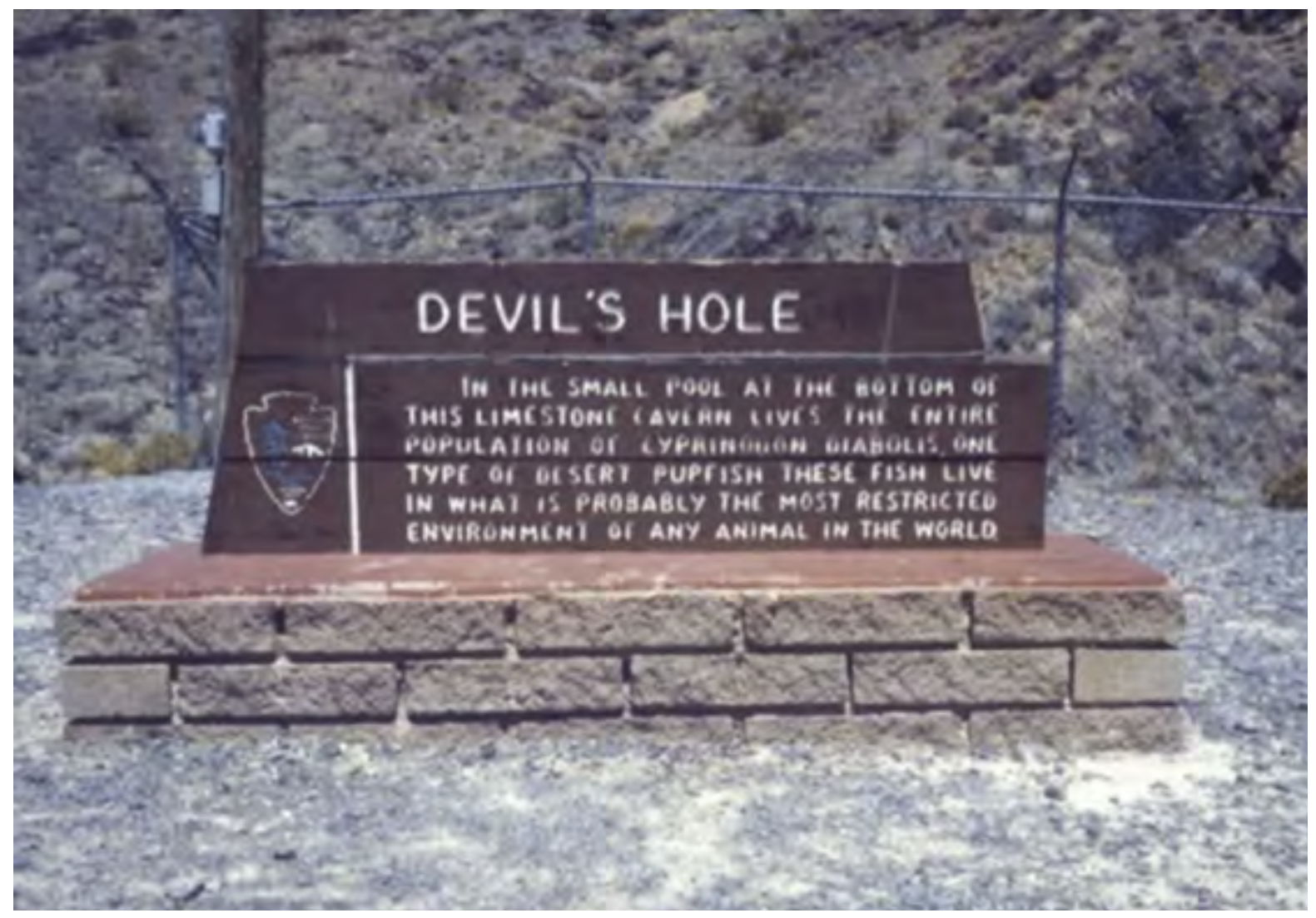

Figure 1. Interpretive sign describing Devils Hole, Death Valley National Park, Nevada. Photograph by R.J. Hoffman, U.S. Geological Survey, 1985 (https://www.sciencebase.gov/catalog/item/58014e74e4b0824b2d18be13). 


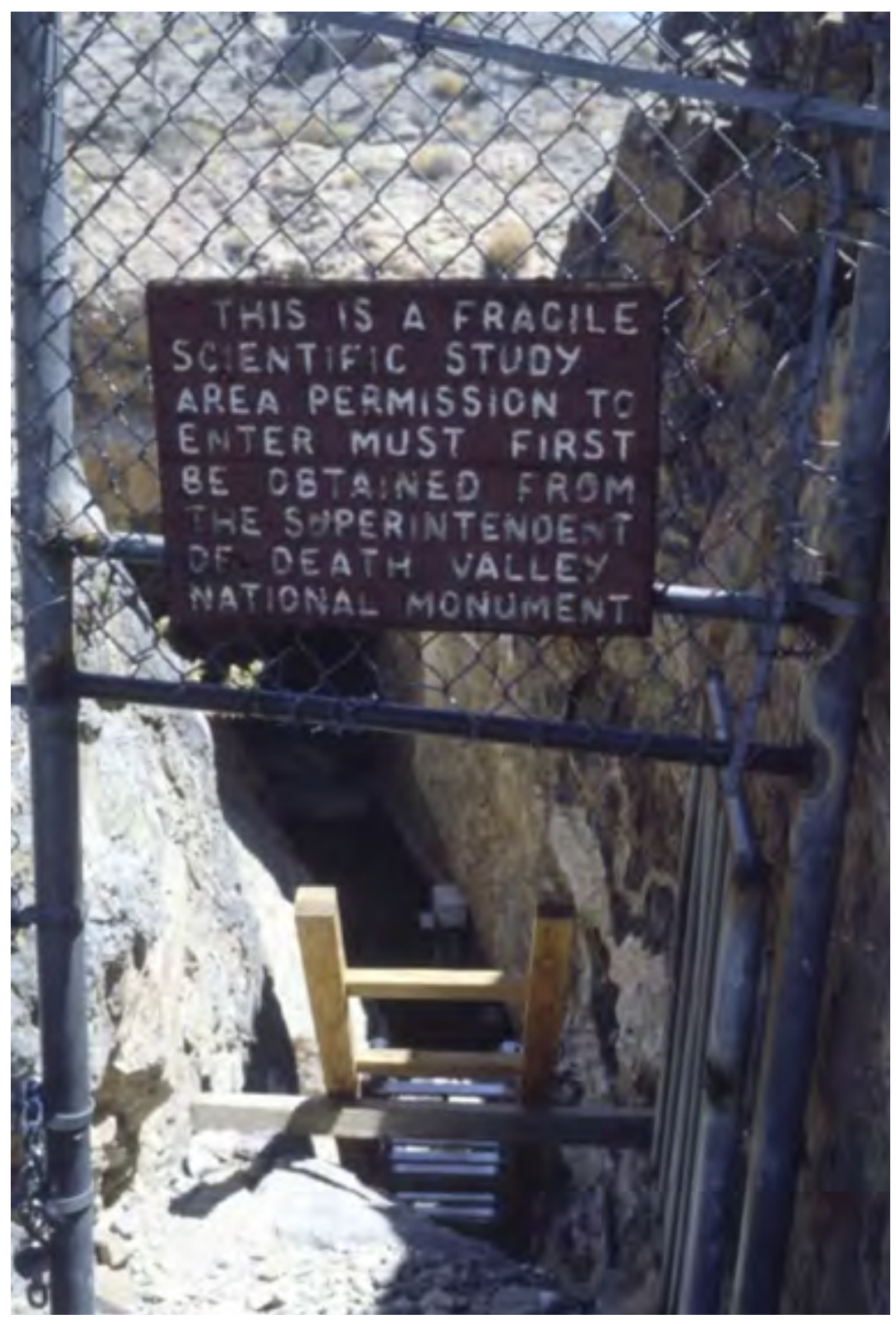

Figure 2. Naturally formed opening of Devils Hole, Death Valley National Park, Nevada. This naturally formed opening to the regional aquifer provides the only known natural habitat for the endangered Devils Hole pupfish (Cyprinodon diabolis). This site also provides the opportunity for scientists to perform novel research in the physical, chemical, and biological sciences, the results of which have local, regional, and global implications. A water-level recorder in wood housing (white) with stilling well is visible near the pool below. Photograph by R.J. Hoffman, U.S. Geological Survey, 1985 (https://www.sciencebase.gov/ catalog/item/5804fd81e4b0824b2d1c1aaa). 


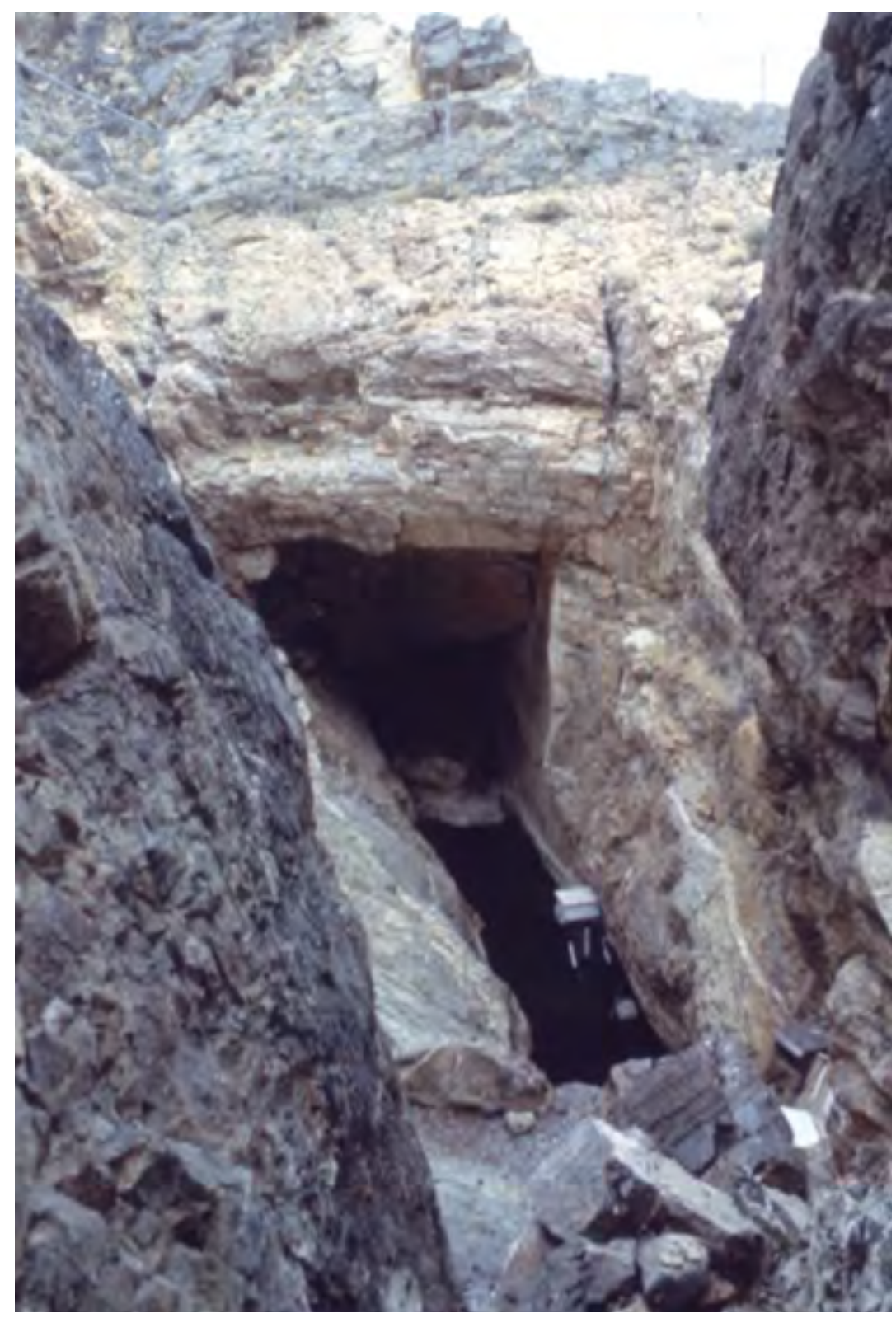

Figure 3. Naturally formed opening of Devils Hole, Death Valley National Park, Nevada. This naturally formed opening to the regional aquifer provides the only known natural habitat for the endangered Devils Hole pupfish (Cyprinodon diabolis). This site also provides the opportunity for scientists to perform novel research in the physical, chemical, and biological sciences, the results of which have local, regional, and global implications. A water-level recorder in wood housing (white) with stilling well is visible near the pool below. Photograph by R.J. Hoffman, U.S. Geological Survey, 1985 (https://www.sciencebase.gov/ catalog/item/5804ffa7e4b0824b2d1c1ab5). 


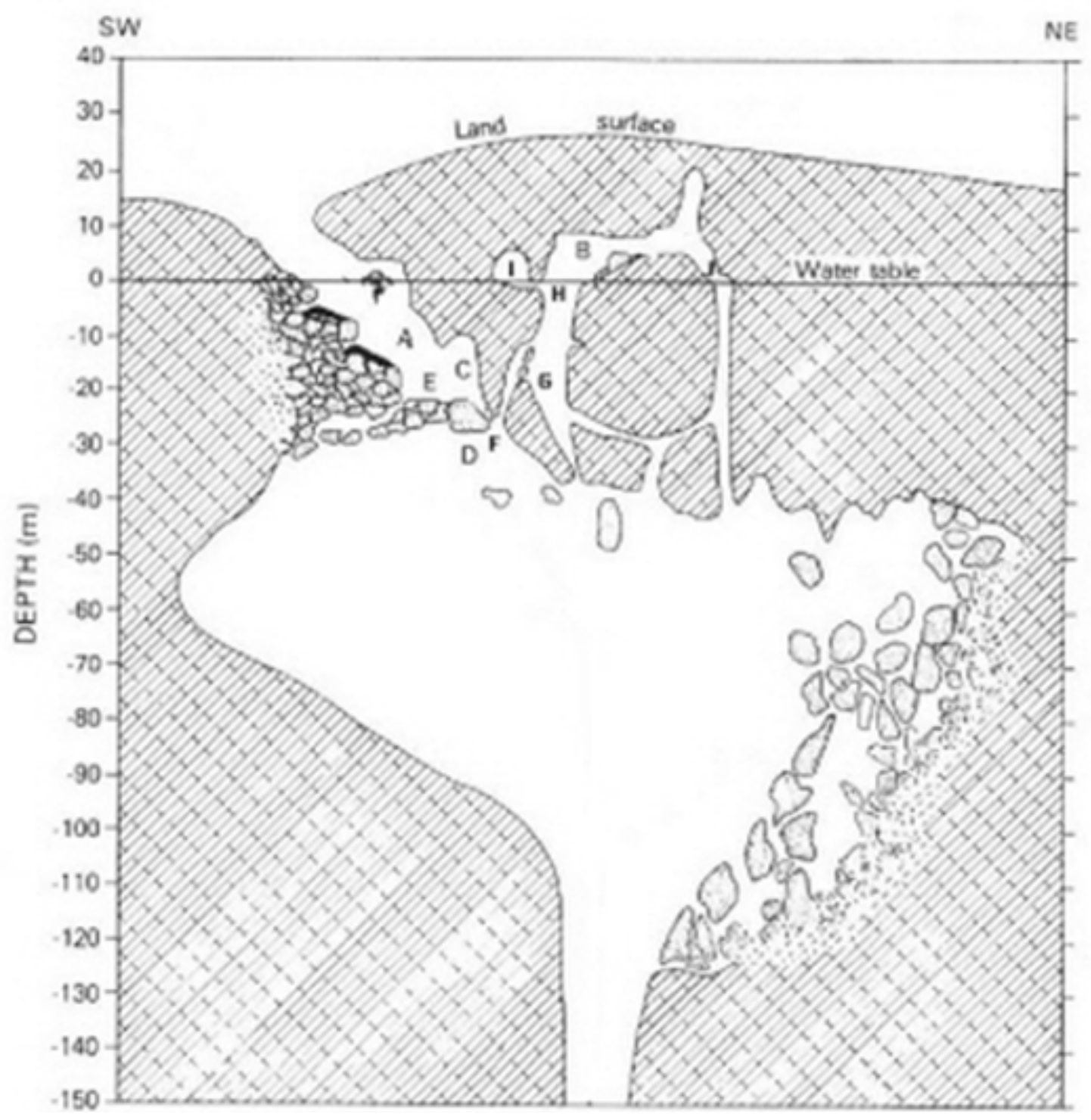

Figure 4. Schematic diagram portraying a southwest-northeast cross section of Devils Hole, Death Valley National Park, Nevada (U.S. Geological Survey, 2005). This figure is modified from Riggs and others (1994). The locations of the photographs showing the internal structures of Devils Hole (figs. 5, 6, and 9-31) are referenced to letters $A$ through $J$ in this figure: figures 5 and 9 are near $A$; figures 6,10 , and $27-31$ are immediately above $D$; figures $11-13$ are above and slightly to the right of $F$; figure 14 is near $G$; figure 15 is at $\mathrm{B}$; figures 16-24 are near the water table surface between $\mathrm{B}$ and $\mathrm{H}$; figure 25 is near $\mathrm{H}$; and figure 26 is below J (https://www.sciencebase.gov/catalog/item/58053885e4b0824b2d1c1e10). 


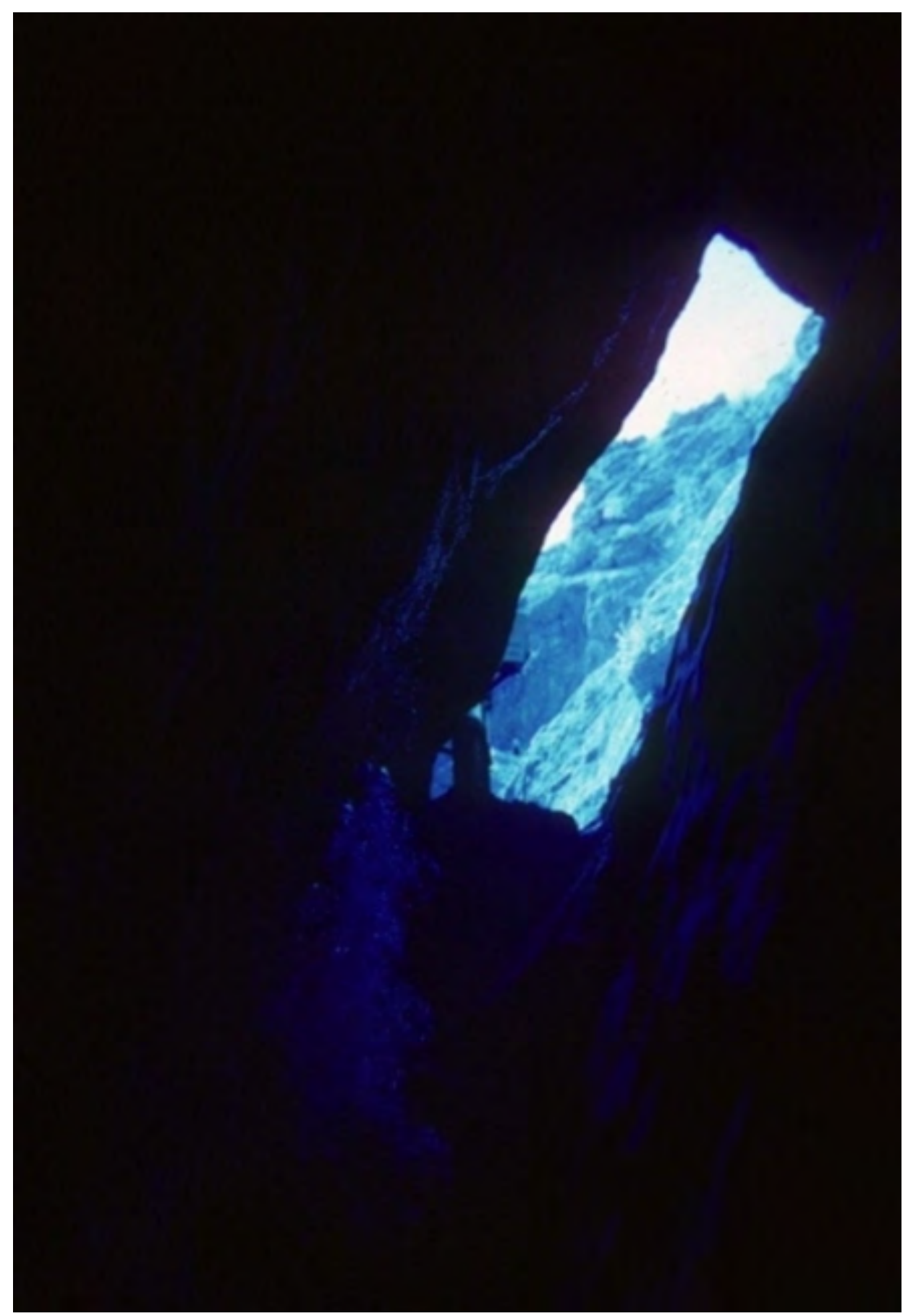

Figure 5. A fish-eye view of Devils Hole, Death Valley National Park, Nevada. View looking up in main chamber at about 20 feet (6.1 meters) below the water surface (near A in fig. 4). The stilling well for a water-level recorder is visible at the water surface near center of the figure, and a diver's exhaled air streams upward towards the surface. Photograph by R.J. Hoffman, U.S. Geological Survey, 1985 (https://www.sciencebase.gov/catalog/ item/58053b33e4b0824b2d1c1e20). 


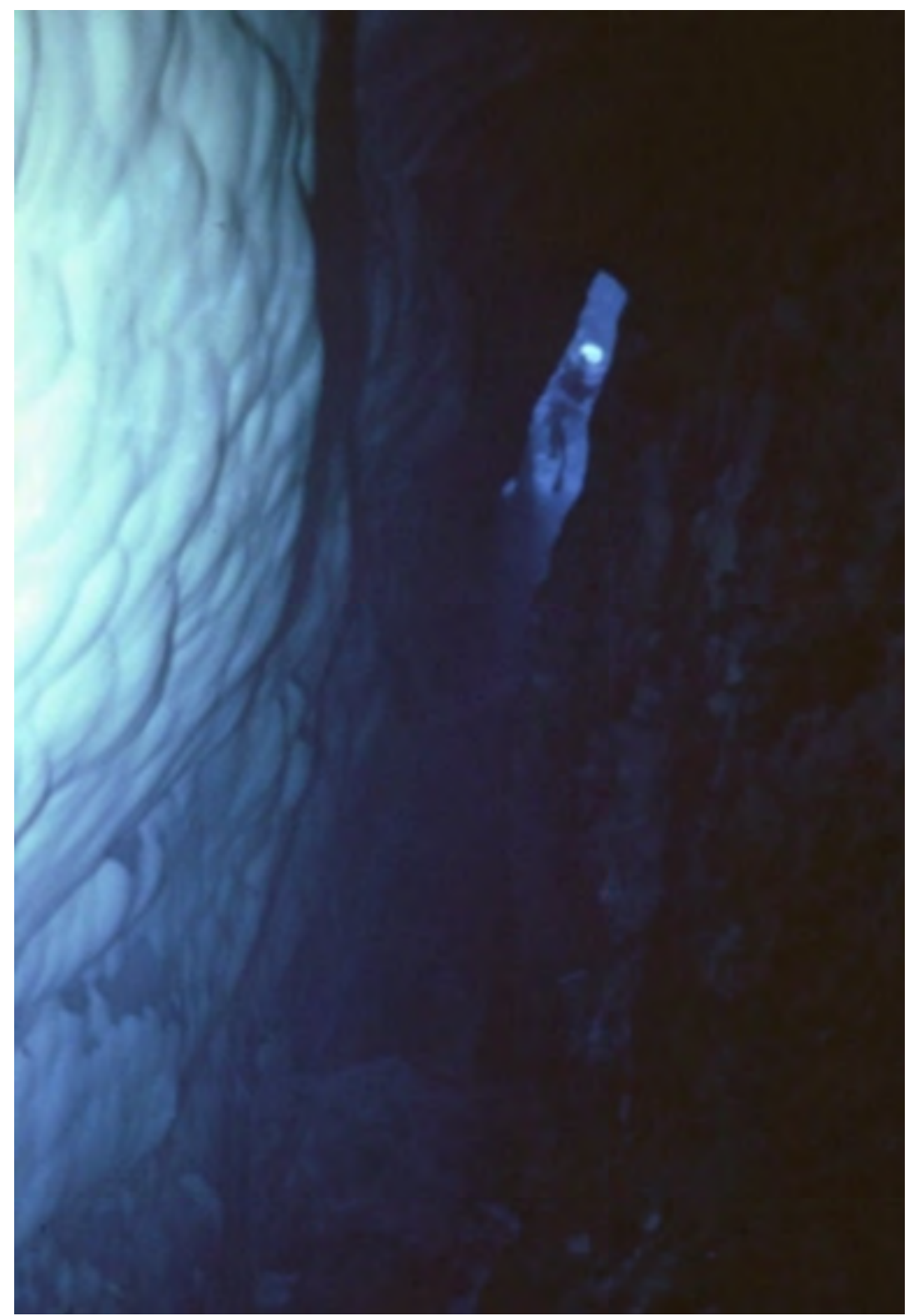

Figure 6. View looking up from Anvil Rock, Devils Hole, Death Valley National Park, Nevada. This view looking up from Anvil Rock (immediately above $D$ in fig. 4) in the main chamber of Devils Hole is from about 80 feet (24.4 meters) below the water surface. The planar fissure strikes northeast and dips 70 to 80 degrees to the southeast. Width of the fissure typically is less than 6.5 feet $(2$ meters). White translucent mammillary calcite (vein calcite) coats the hanging wall (on the left) of Paleozoic carbonate bedrock. Footwall (on the right) is barely visible in the narrow fissure. Two U.S. Geological Survey research divers are at the pool. Photograph by R.J. Hoffman, U.S. Geological Survey, 1985 (https://www.sciencebase.gov/catalog/item/58053c7de4b0824b2d1c1e2c). 


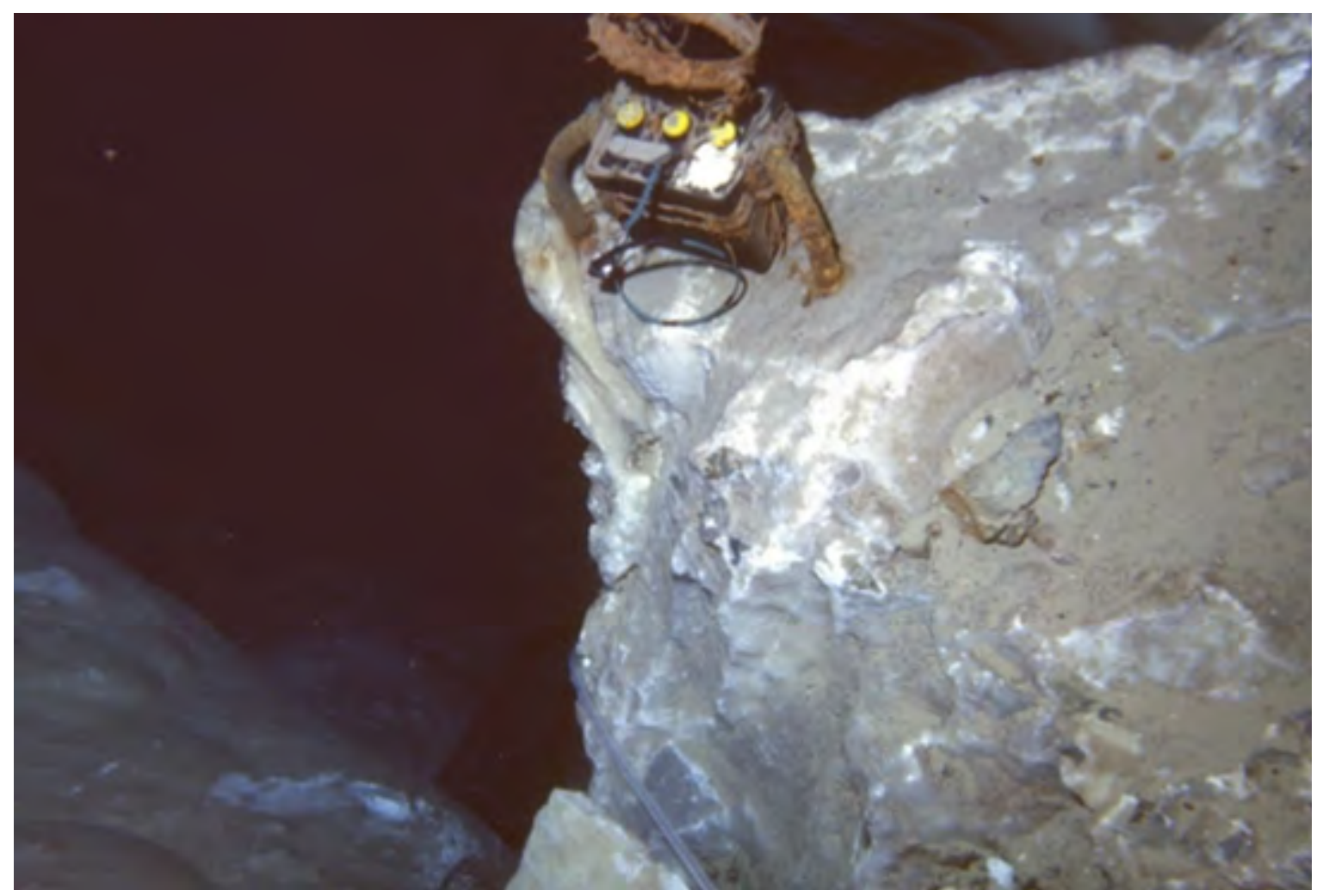

Figure 7. Battery Rock, Devils Hole, Death Valley National Park, Nevada. This rock is at a depth of about 150 feet (45.7 meters) below the water surface. The rock is so named because this battery was used to power an underwater light, and it was left during a fruitless search in 1965 for two missing divers. The rock itself is a large breakdown block that became dislodged from above, fell, and became wedged in the relatively narrow fissure. The clear plastic tube at bottom center of the figure was used to transport water samples at depth to the surface for collection and later chemical analyses at the laboratory. Photograph by R.J. Hoffman, U.S. Geological Survey, 1985 (https://www.sciencebase.gov/catalog/item/58053f02e4b0824b2d1c1e34). 


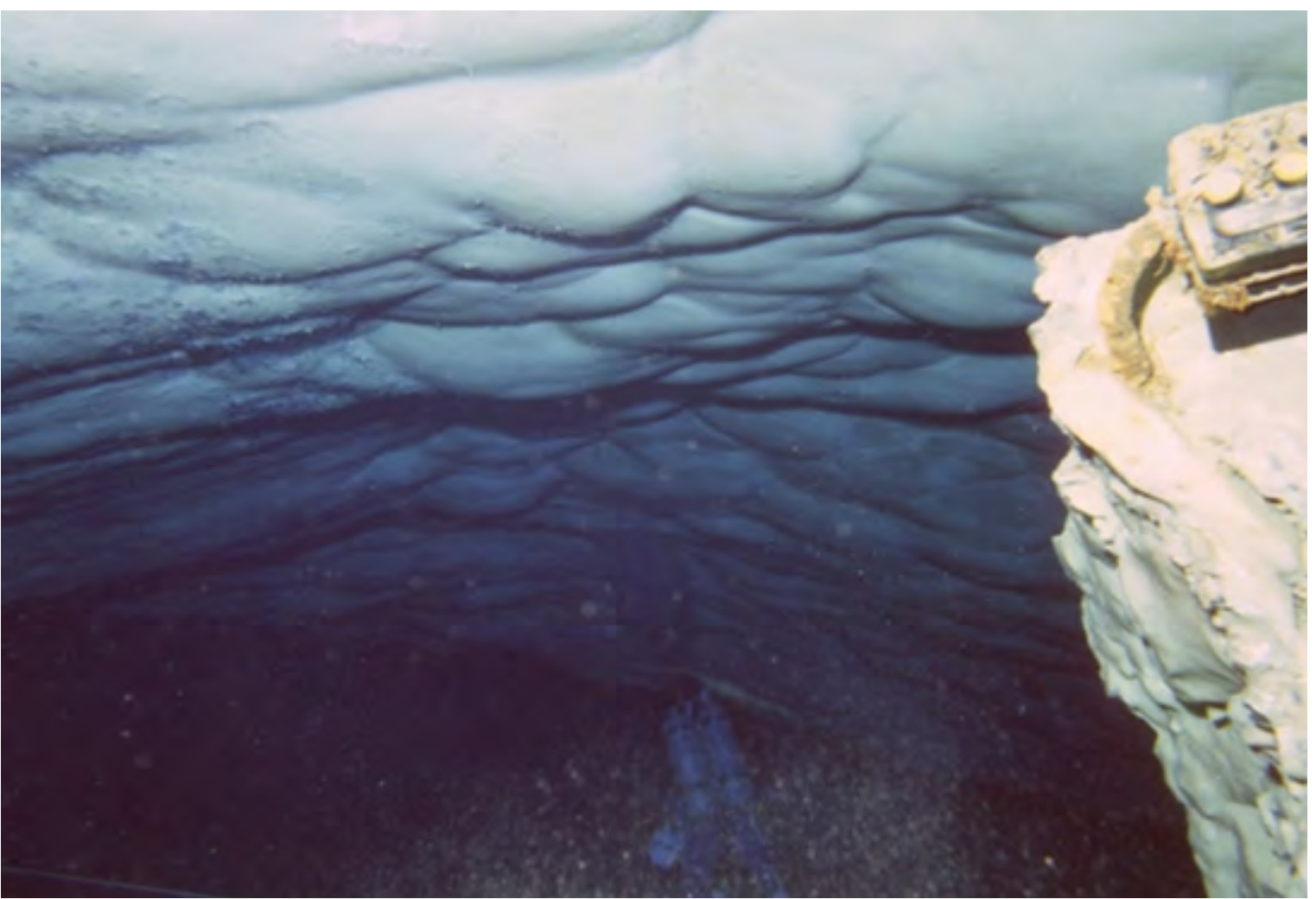

Figure 8. View looking down from Battery Rock, Devils Hole, Death Valley National Park, Nevada. This view shows a corner of Battery Rock at about 150 feet (45.7 meters) below the water surface and a U.S. Geological Survey research diver, who is about 200 feet (61 meters) below the water surface. Note the coating of mammillary calcite (vein calcite) on the hanging wall. The water is slightly supersaturated with respect to calcite. Photograph by R.J. Hoffman, U.S. Geological Survey, 1985 (https://www.sciencebase.gov/catalog/ item/580541b0e4b0824b2d1c1e49). 


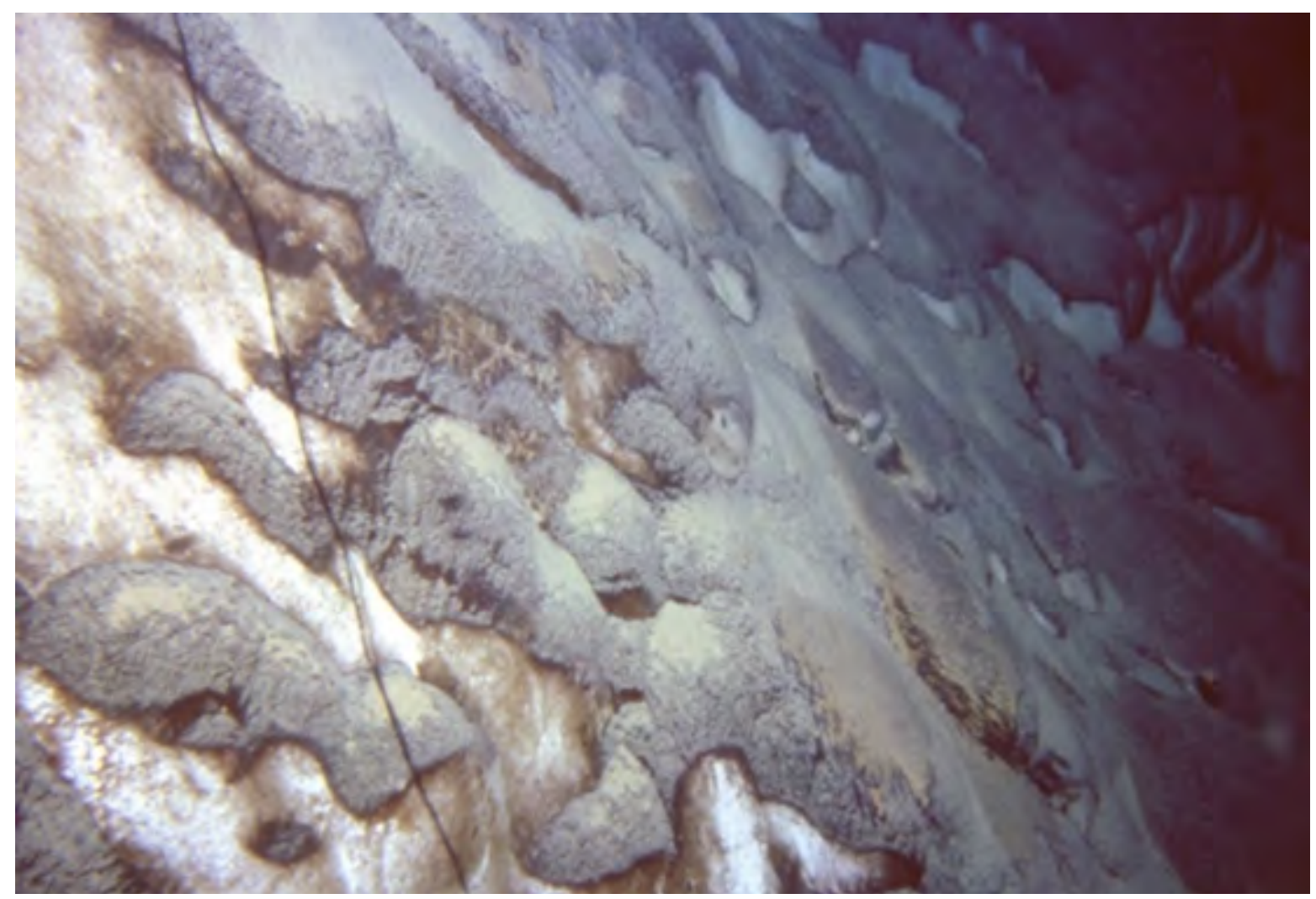

Figure 9. Footwall in the main chamber, Devils Hole, Death Valley National Park, Nevada. This footwall in the main chamber of Devils Hole is composed of Paleozoic carbonate bedrock covered by mammillary calcite (in some areas discolored with rock varnish) and partially coated with sediment (near A in fig. 4). Sediment is mainly from episodic surface runoff. Depth is about 25 feet (7.6 meters) below the water surface. The near-vertical black line on the left is a telephone cable that was strung between the outside entrance of Devils Hole to Browns Room, a large air-filled subterranean chamber (fig. 15 and B in fig. 4), by divers of the National Speleological Society in 1954 or 1961. The cable has since been removed. Photograph by R.J. Hoffman, U.S. Geological Survey, 1986 (https://www.sciencebase.gov/catalog/item/580782b4e4b0841e59e3a0ed). 


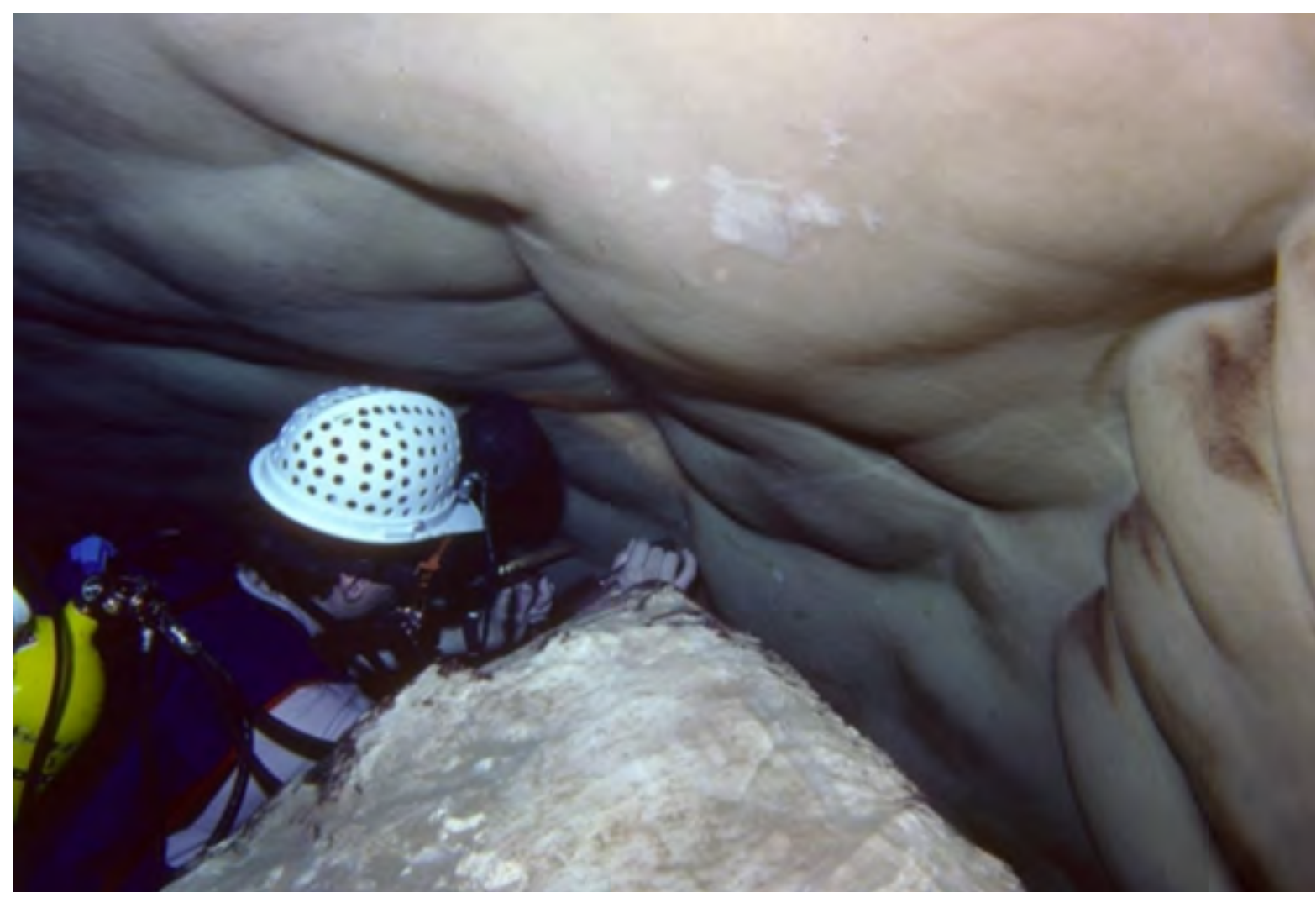

Figure 10. U.S. Geological Survey research diver near Anvil Rock, Devils Hole, Death Valley National Park, Nevada. The research diver is chiseling a small survey mark on the hanging wall of mammillary calcite near Anvil Rock (immediately above D in fig. 4) in the main chamber of Devils Hole. Depth is about 80 feet (24.4 meters) below the water surface. The rock partially visible in the center of the figure is a piece of breakdown. Note the scar on the hanging wall, presumably resulting from impact by fallen breakdown. Rock varnish is visible on several up-facing ledges of mammillary calcite (on the right). Also note the high clarity of the water. Photograph by R.J. Hoffman, U.S. Geological Survey, 1986 (https://www.sciencebase.gov/catalog/item/580784d1e4b0841e59e3a0fc). 


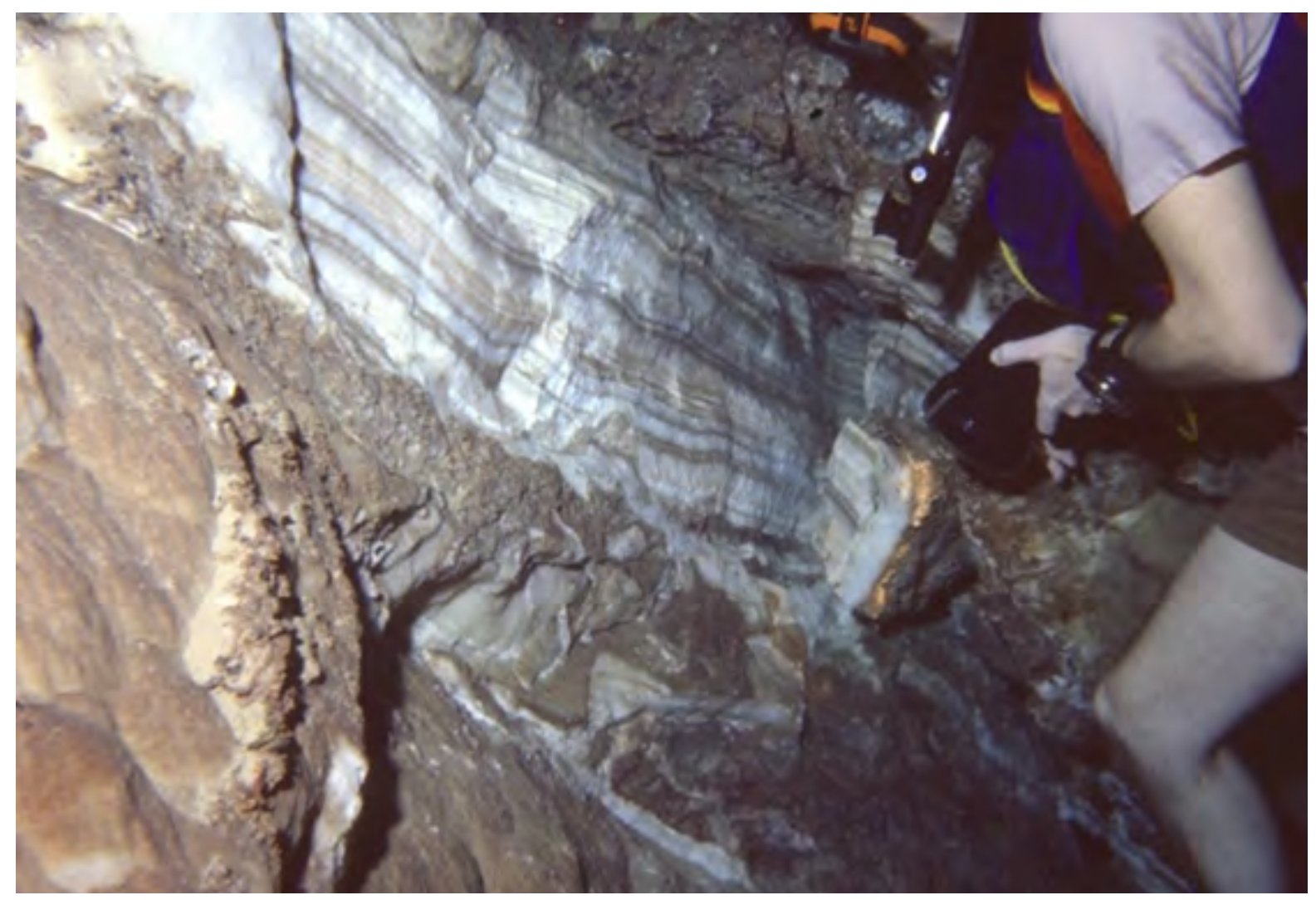

Figure 11. Exposed cross section of mammillary calcite and U.S. Geological Survey research diver in the main chamber of Devils Hole, Death Valley National Park, Nevada. This cross section of mammillary calcite in main chamber of Devils Hole (near entrance to Browns Room, above and slightly to the right of F in fig. 4) shows dark bands of sediment cemented into the mammillary coating by continual calcite precipitation. Depth is about 80 feet (24.4 meters) below the water surface. Photograph by R.J. Hoffman, U.S. Geological Survey, 1986 (https://www.sciencebase.gov/catalog/item/5807867ce4b0841e59e3a10b). 


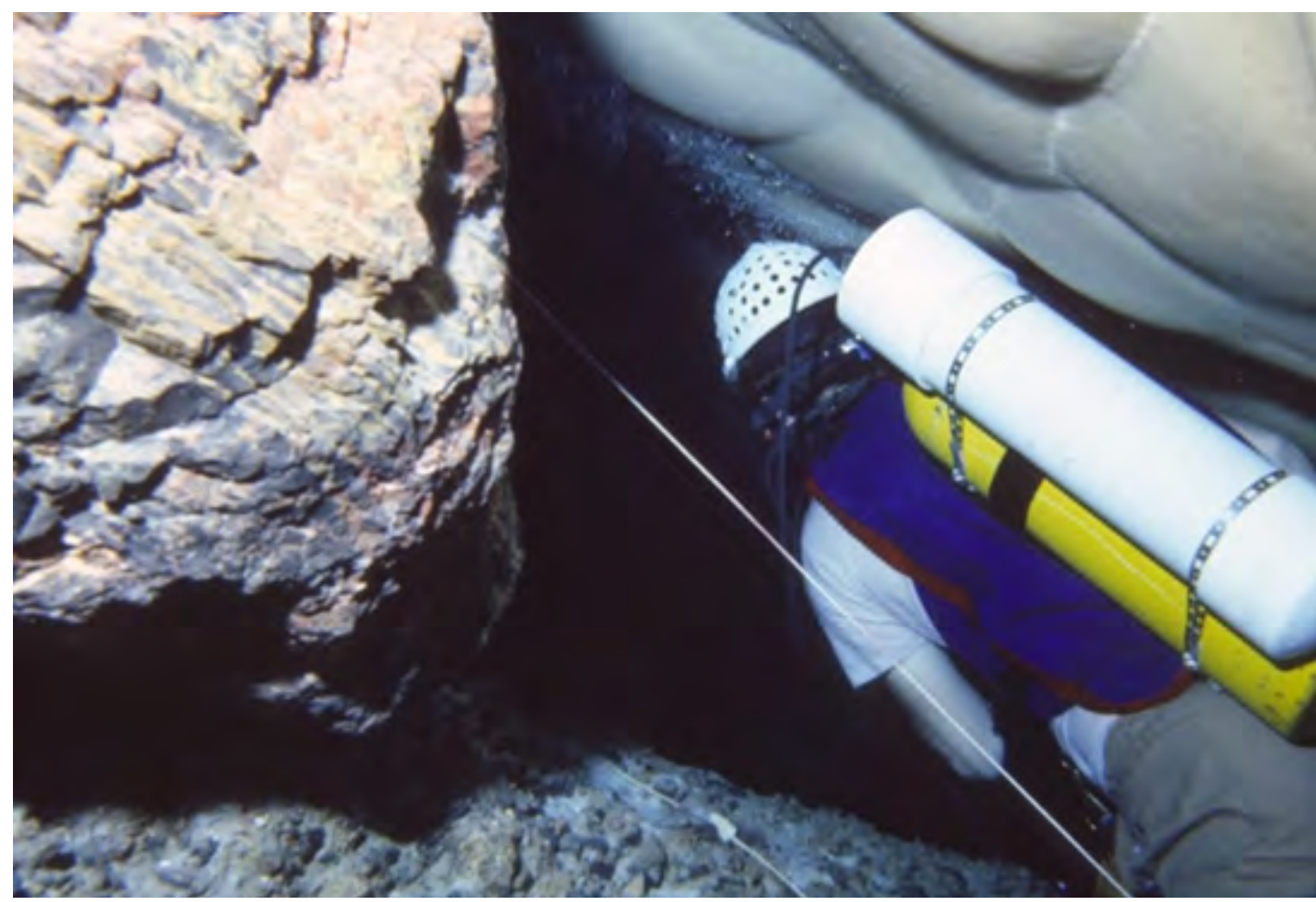

Figure 12. U.S. Geological Survey research diver at entrance to narrow passageway in the main chamber of Devils Hole, Death Valley National Park, Nevada. This entrance (above and slightly to right of F in fig. 4) allows access to Browns Room. Nylon safety guideline is just to the left of diver. White PVC (polyvinyl chloride) case attached to scuba tank is housing for battery pack to power helmet-mounted dive light. Depth is about 80 feet (24.4 meters) below the water surface. Photograph by R.J. Hoffman, U.S. Geological Survey, 1986 (https://www.sciencebase.gov/catalog/item/5807a4d2e4b0841e59e3a1a3). 


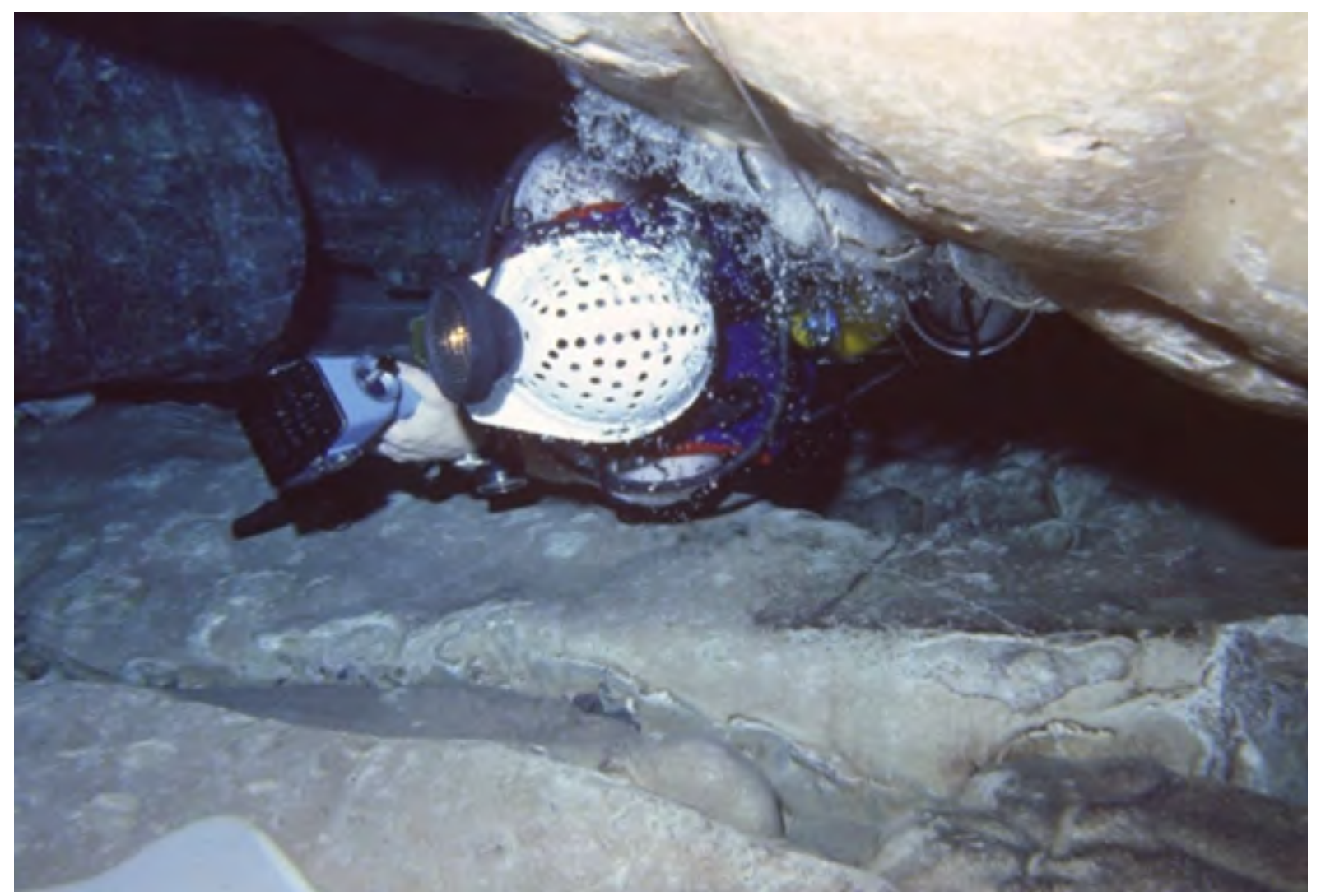

Figure 13. U.S. Geological Survey research diver in a passageway, Devils Hole, Death Valley National Park, Nevada. The research diver is squeezing through the narrow passageway that connects the main chamber of Devils Hole to Browns Room (continuation of fig. 12). Photograph by R.J. Hoffman, U.S. Geological Survey, 1986 (https://www.sciencebase.gov/catalog/item/5807a712e4b0841e59e3a3d9). 


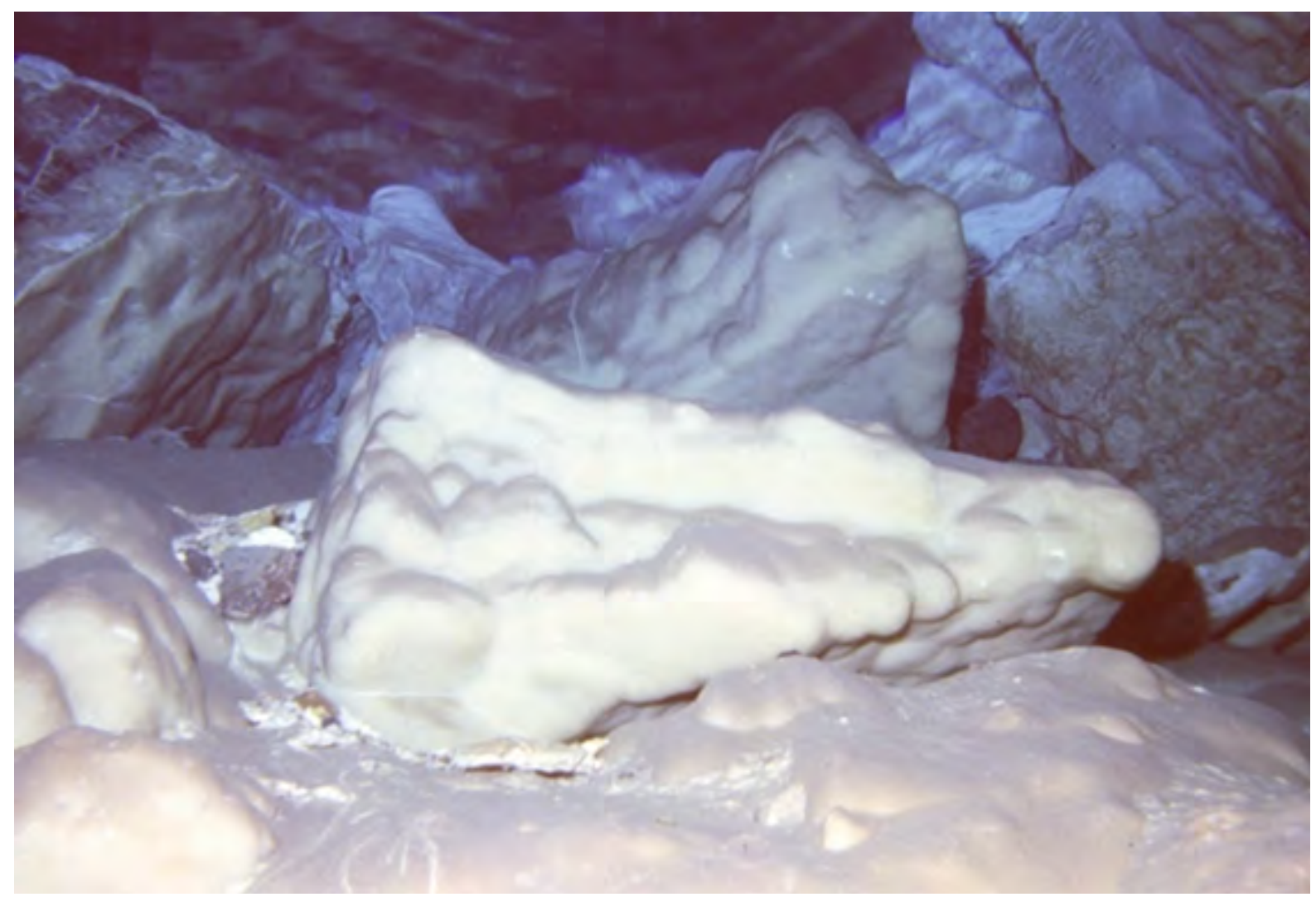

Figure 14. Mammillary calcite, Browns Room, Devils Hole, Death Valley National Park, Nevada. A piece of breakdown coated with mammillary calcite [length about 4 feet (1.2 meters)] is shown in the entrance to Browns Room (near $\mathrm{G}$ in fig. 4). Depth is about 60 feet (18.3 meters) below the water surface. The water surface of the pool in Browns Room is visible near the top of the photograph. Photograph by R.J. Hoffman, U.S. Geological Survey, 1986 (https://www.sciencebase.gov/catalog/item/5807a8bfe4b0841e59e3a41e). 


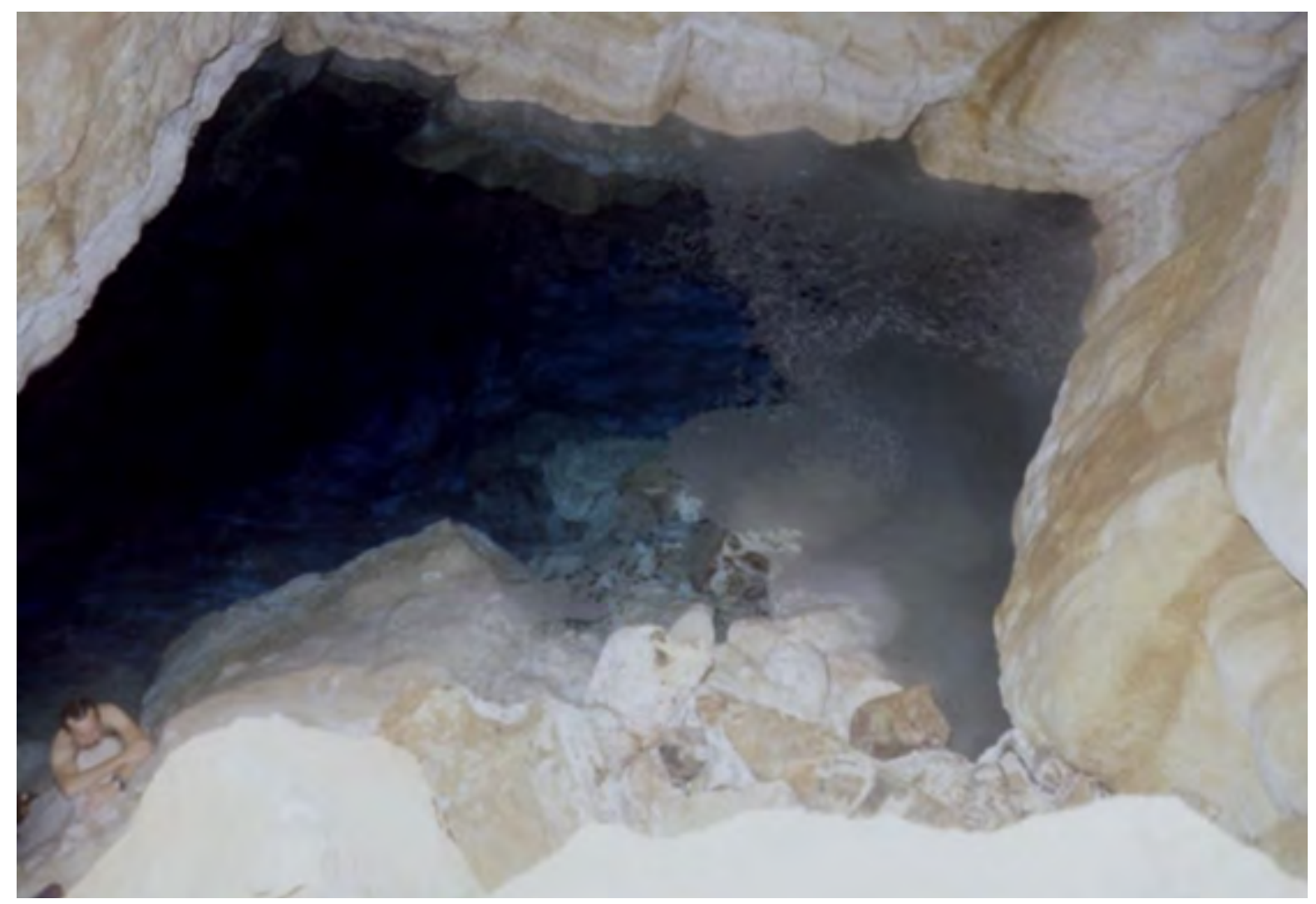

Figure 15. Browns Room and pool, Devils Hole, Death Valley National Park, Nevada. The photograph was taken from atop the largest breakdown boulder shown in figure 16. Browns Room is B in fig. 4. The chamber was named after its discoverer William Brown in 1953. Note diver in pool at bottom left corner for scale. Also note calcite rafts floating on nearly one-third of the water surface (like winter ice on a lake) to the right in the figure. These rafts are formed at the air-water interface. They are diaphanous in appearance and to the touch (of millimeter or less thickness). They eventually sink to the bottom owing to their weight exceeding their buoyancy or owing to external disturbance-for example, by wave action caused by an earthquake or fallen rock, or, specifically in Browns Room, by infrequent human activity since recorded entry by scuba in 1953. (Also see fig. 20.) Photograph by R.J. Hoffman, U.S. Geological Survey, 1986 (https://www.sciencebase.gov/catalog/item/5807ac0ee4b0841e59e3a42d). 


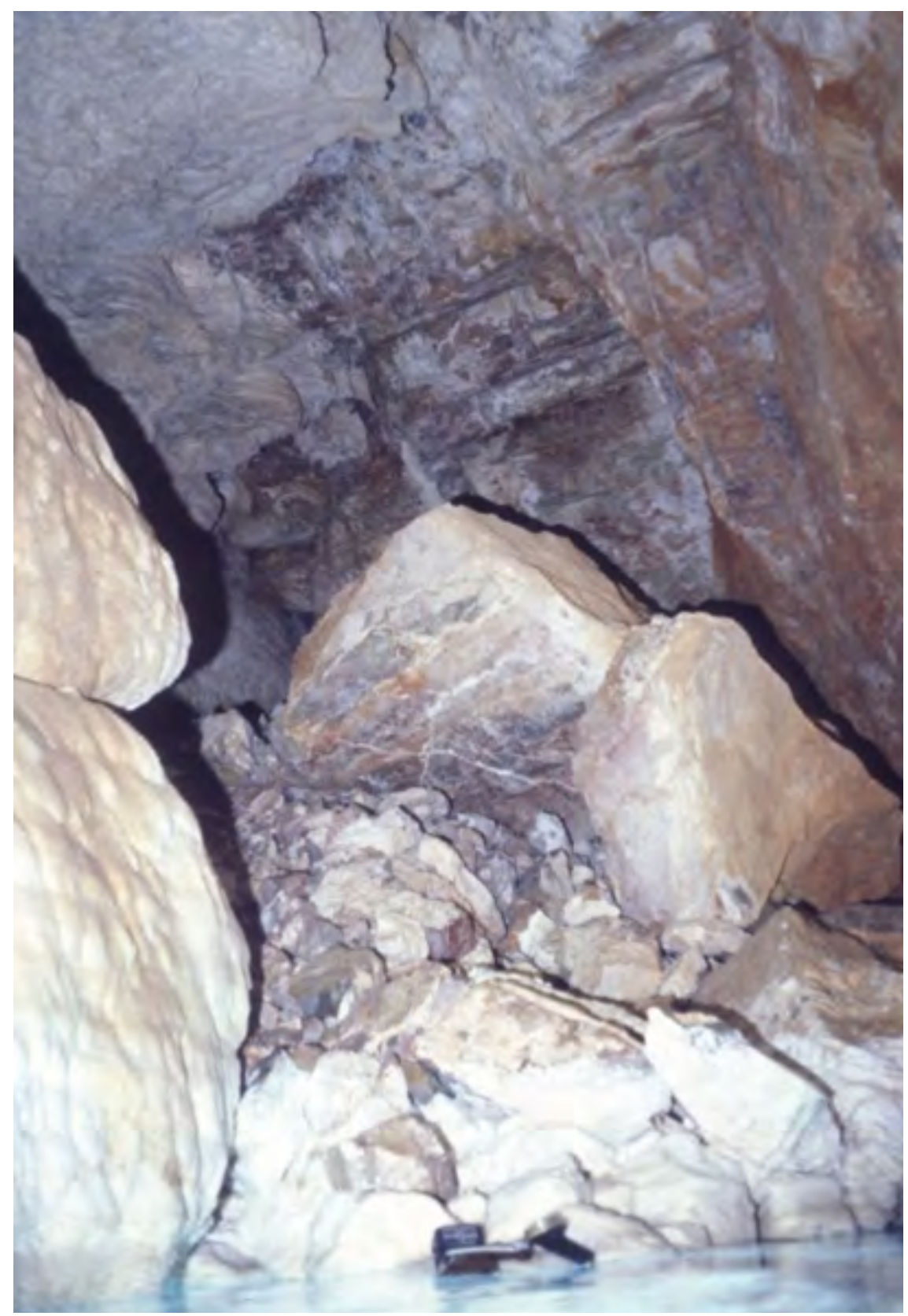

Figure 16. Breakdown debris near the pool in Browns Room, Devils Hole, Death Valley National Park, Nevada. Large blocks of breakdown that fell from the ceiling are resting atop smaller breakdown debris near the pool in Browns Room (to right of $B$ in fig. 4). For scale, note dive light and dive computer at water's edge in pool. Previous figure (fig. 15) was taken from atop the largest breakdown boulder. Above-water passageway to Leinhaupel's Pool (fig. 26) continues several meters to left (northeast) in this figure, but with minimal breakdown debris along the floor. East wall is in background. Photograph by R.J. Hoffman, U.S. Geological Survey, 1986 (https://www.sciencebase.gov/catalog/item/58090f25e4b0f497e78f3e3a). 


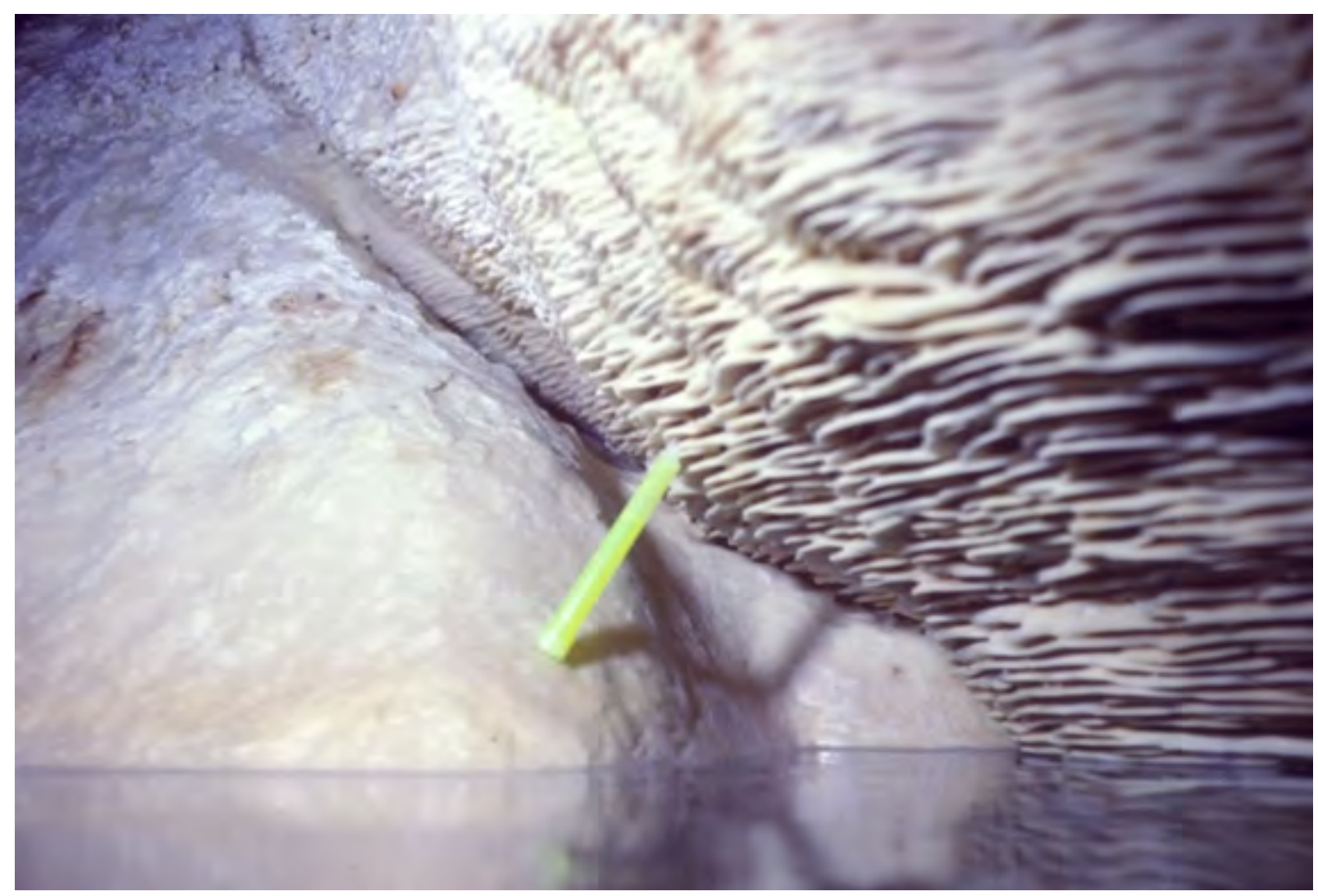

Figure 17. Folia in the northeast corner of the pool in Browns Room, Devils Hole, Death Valley National Park, Nevada. Folia typically form at the air-water-substrate interface on down-facing (hanging wall) surfaces or on breakdown surfaces. The chemical light is about 6-inches (15.2-centimeters) long, and it bridges folia on the hanging wall and flowstone(?) on the footwall. Photograph by R.J. Hoffman, U.S. Geological Survey, 1986 (https://www.sciencebase.gov/catalog/item/580911a0e4b0f497e78f3e4d). 


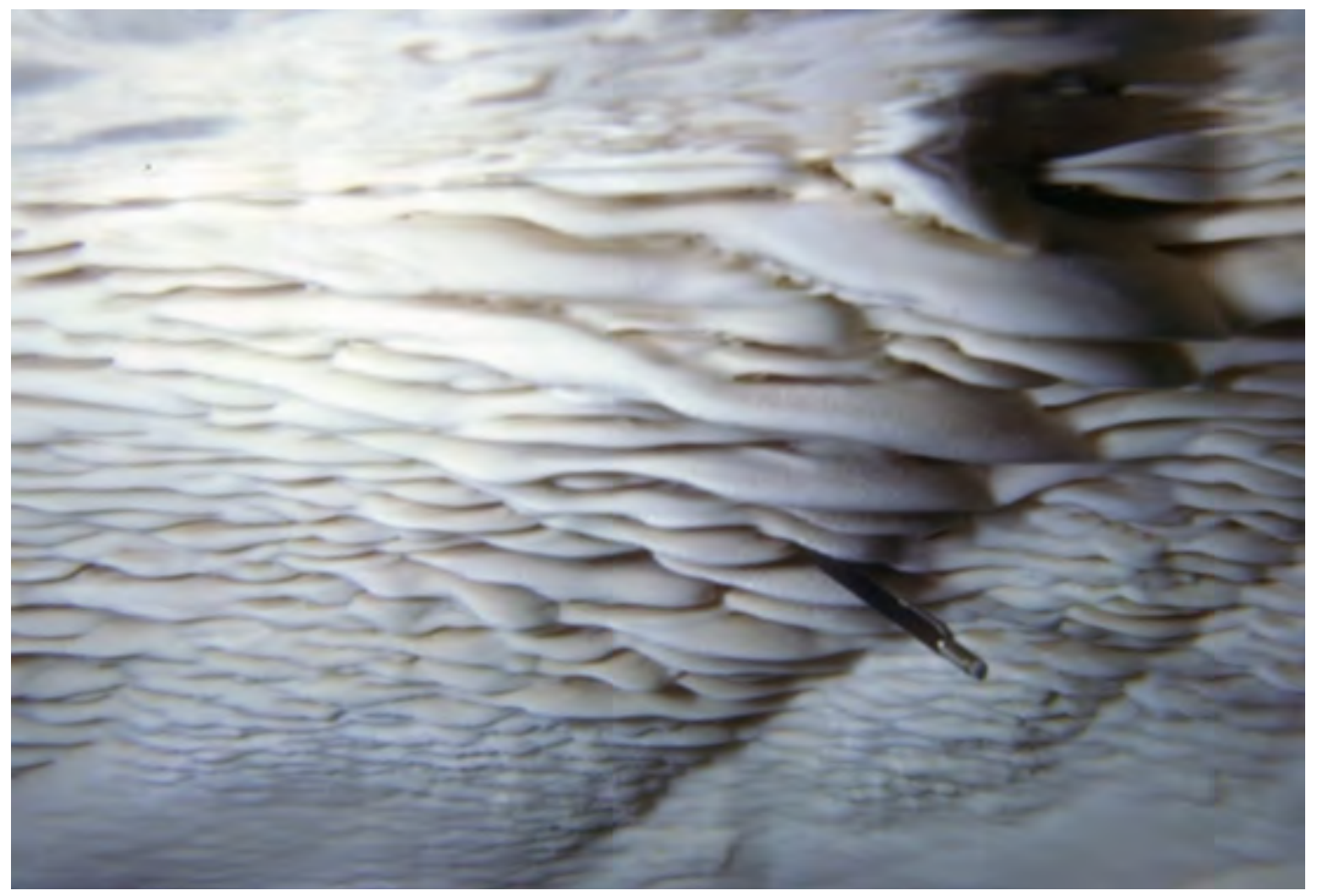

Figure 18. Folia in pool in Browns Room, Devils Hole, Death Valley National Park, Nevada. These folia are just below the water surface (visible at top of figure) in the pool in Browns Room. The mechanical pencil is about 5-inches (12.7-centimeters) long. Photograph by R.J. Hoffman, U.S. Geological Survey, 1986 (https://www.sciencebase.gov/catalog/item/5809330de4b0f497e78f3ec3). 


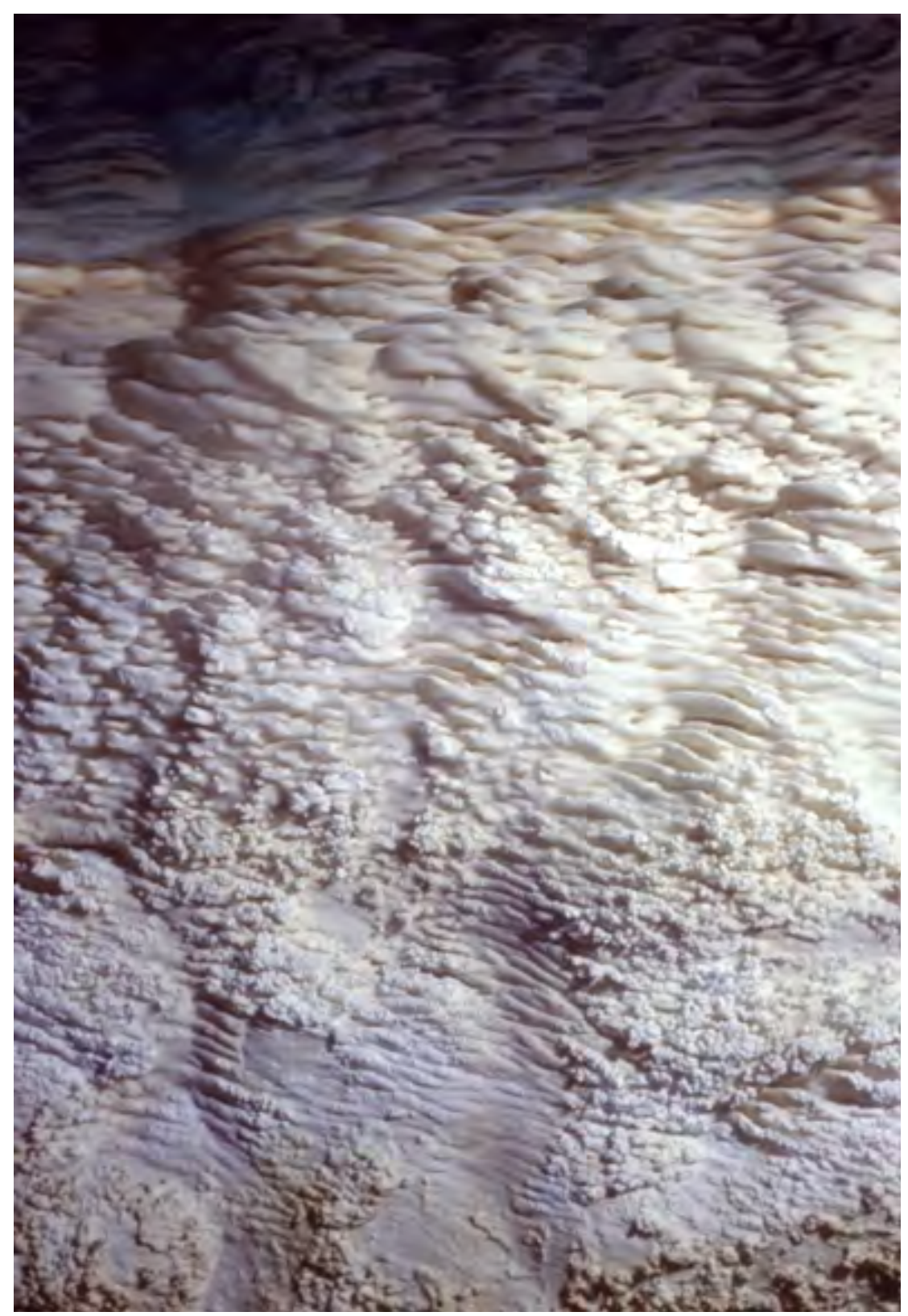

Figure 19. Folia and popcorn at the northeast corner of the pool in Browns Room, Devils Hole, Death Valley National Park, Nevada. Folia and popcorn, two different types of speleothems precipitated respectively at or above the paleo water table (seen at top of figure), are shown at the northeast corner of the pool in Browns Room. From the water surface to the bottom of the figure is about 4 feet (1.2 meters). The occurrence of both popcorn and folia underwater suggest that the water table was lower in the past. Photograph by R.J. Hoffman, U.S. Geological Survey, 1986 (https://www.sciencebase.gov/catalog/item/580934b5e4b0f497e78f3ef0). 


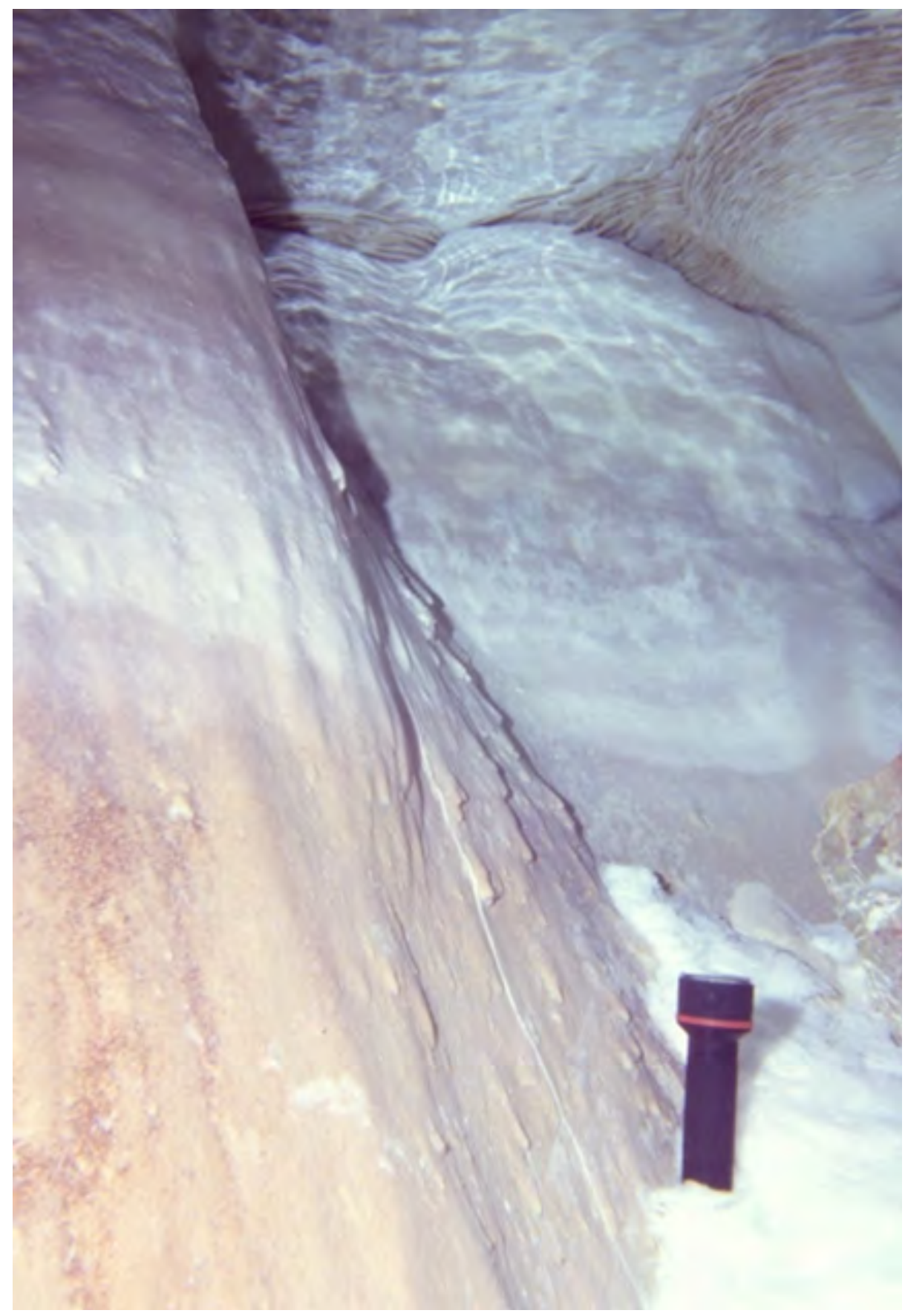

Figure 20. Dive light by the west wall of Browns Room, Devils Hole, Death Valley National Park, Nevada. The dive light [about 8-inches (20-centimeters) long] is resting vertically on accumulation of sunken calcite rafts about 4 feet (1.2 meters) below the water surface, by the west wall of Browns Room. The accumulation resembles a miniature talus slope. The water surface and folia are visible near the top and right corner of the figure, respectively. Photograph by R.J. Hoffman, U.S. Geological Survey, 1986 (https://www.sciencebase.gov/catalog/item/58093af2e4b0f497e78f40ce). 


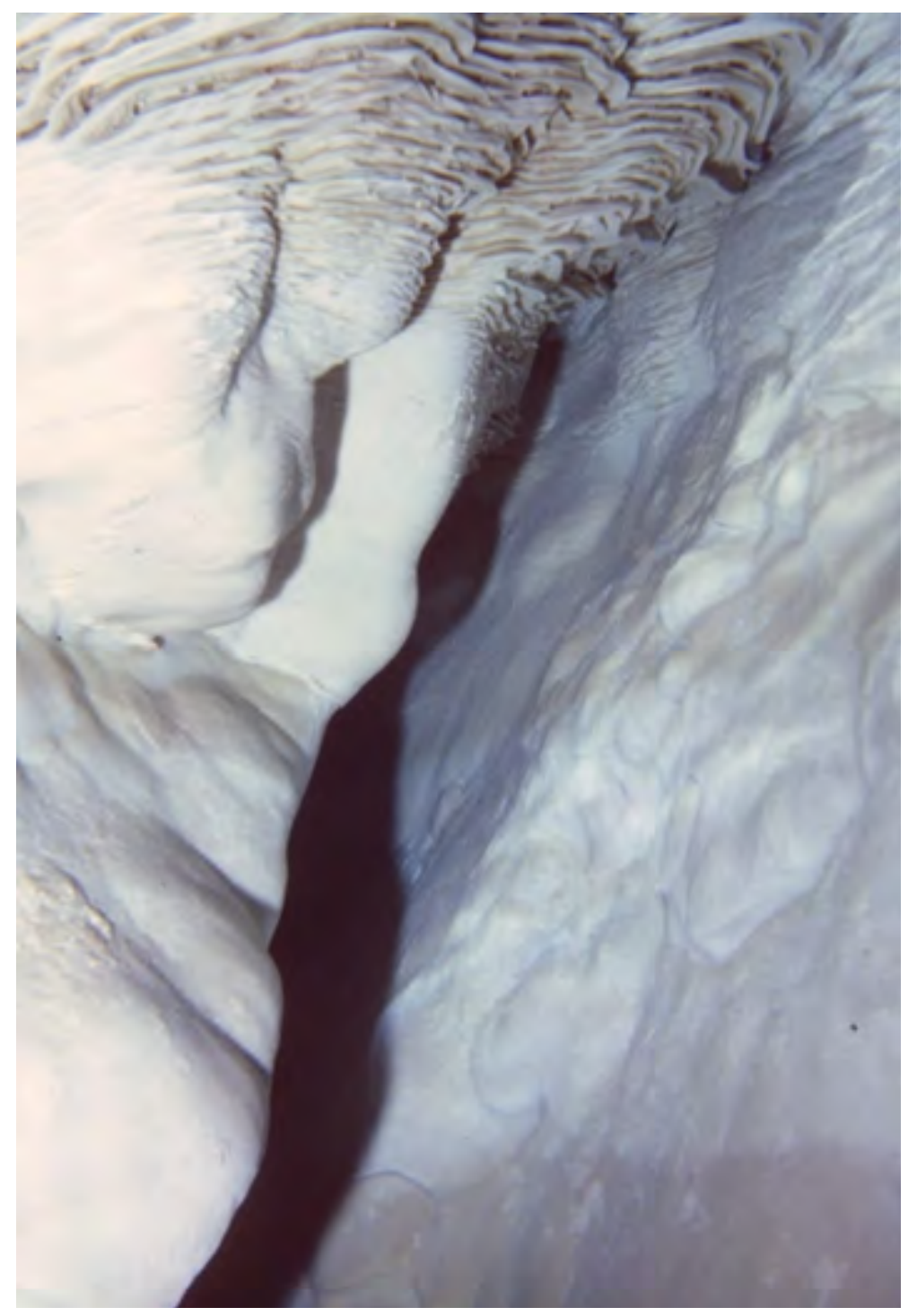

Figure 21. Folia and mammillary calcite below water surface in the southwest corner of Browns Room, Devils Hole, Death Valley National Park, Nevada. The photograph was taken about 3.3 feet (1 meter) below the water surface in the southwest comer of the pool in Browns Room. Folia are present below the water surface (near top of figure) and mammillary calcite coating is below. The west wall is to the right in the figure and the south wall is to the left along an apparent fault line with some vertical displacement. The reason for the discoloration at about 3.3 feet (1 meter) below the water surface is unknown, but surfaces are discolored elsewhere in the main pool in Browns Room (figs. 20 and 24) and in Leinhaupel's Pool. Photograph by R.J. Hoffman, U.S. Geological Survey, 1986 (https://www.sciencebase.gov/catalog/item/580a384ee4b0f497e79063da). 


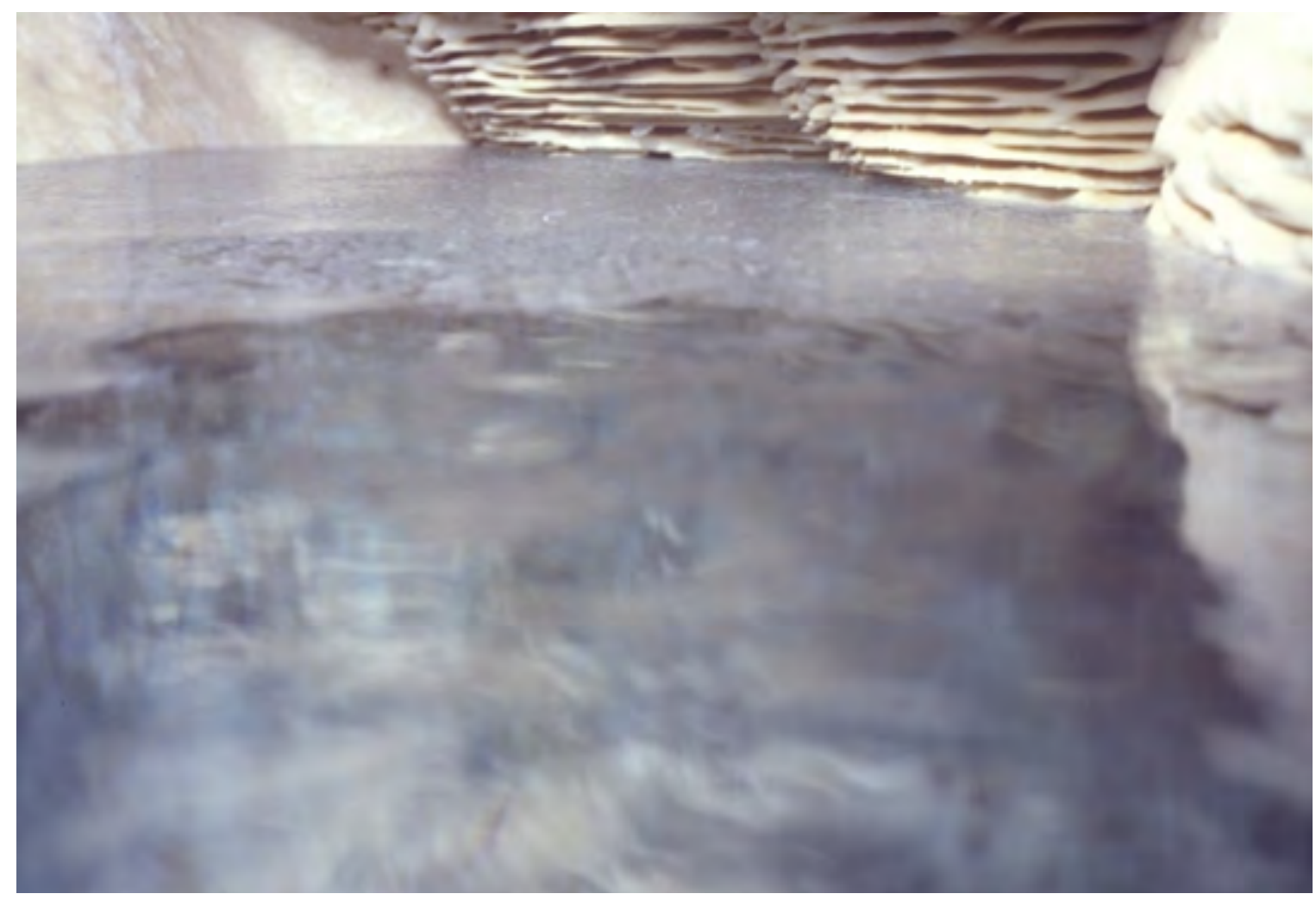

Figure 22. Folia just above the water surface in Browns Room, Devils Hole, Death Valley National Park, Nevada. Folia are just above the water surface in the pool along the west wall in Browns Room. Note the thin coating of calcite rafts floating on the water surface. Also note the small stranded rafts cemented between fins of folia, forming a honeycomb-like structure. Photograph by R.J. Hoffman, U.S. Geological Survey, 1986 (https://www.sciencebase.gov/catalog/item/580a3fbbe4b0f497e7906415). 


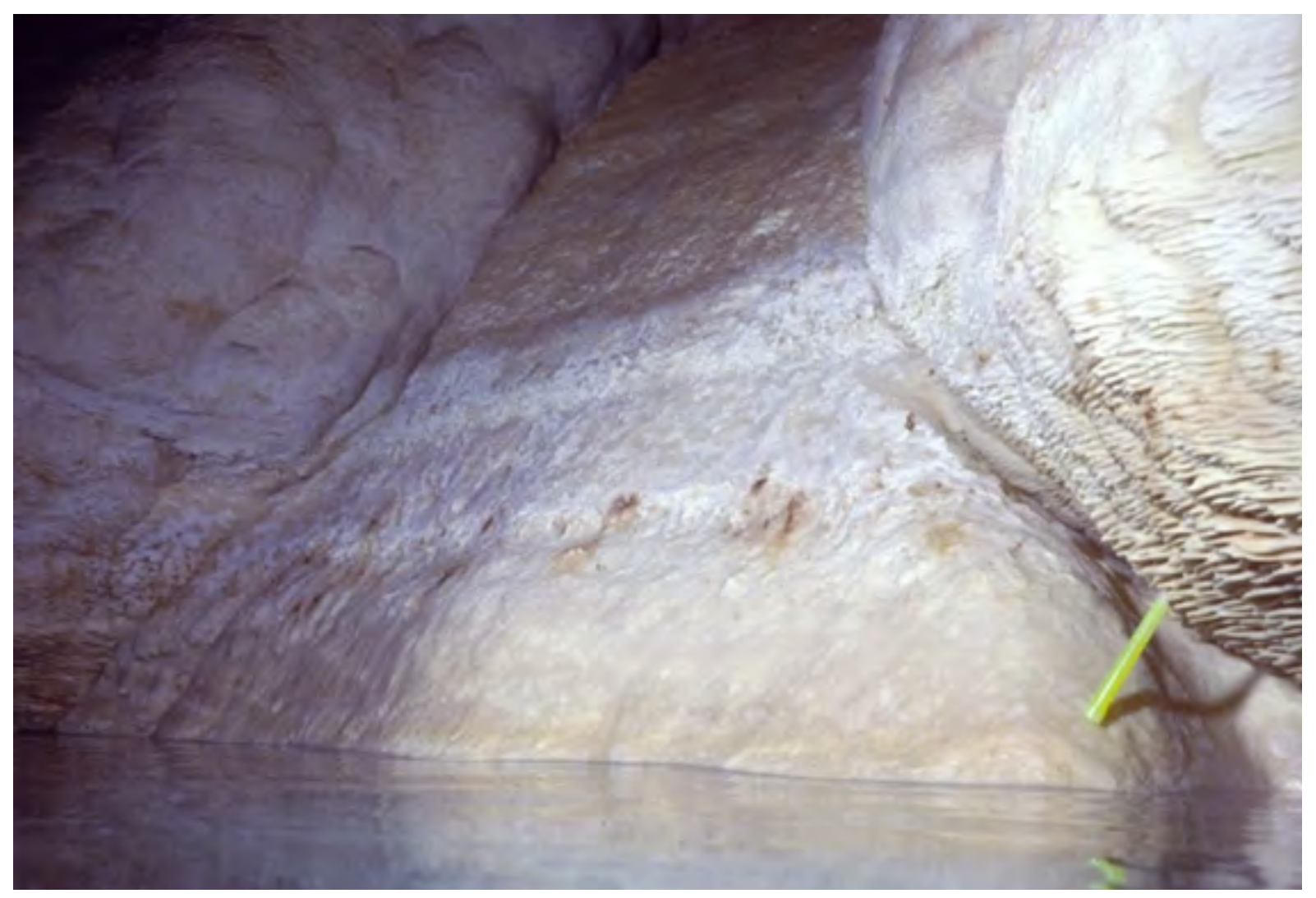

Figure 23. Pool in the northwest corner of Browns Room, Devils Hole, Death Valley National Park, Nevada. Chemical light is about 6 -inches (15-centimeters) long. Note that folia typically form on vertical-to-overhanging surfaces, as seen at extreme right and left in figure near the water surface. Horizontal color bands ("bathtub rings") on the upward-facing slope mark former higher water levels. Photograph by R.J. Hoffman, U.S. Geological Survey, 1986 (https://www.sciencebase.gov/catalog/item/580a410ce4b0f497e790642c). 


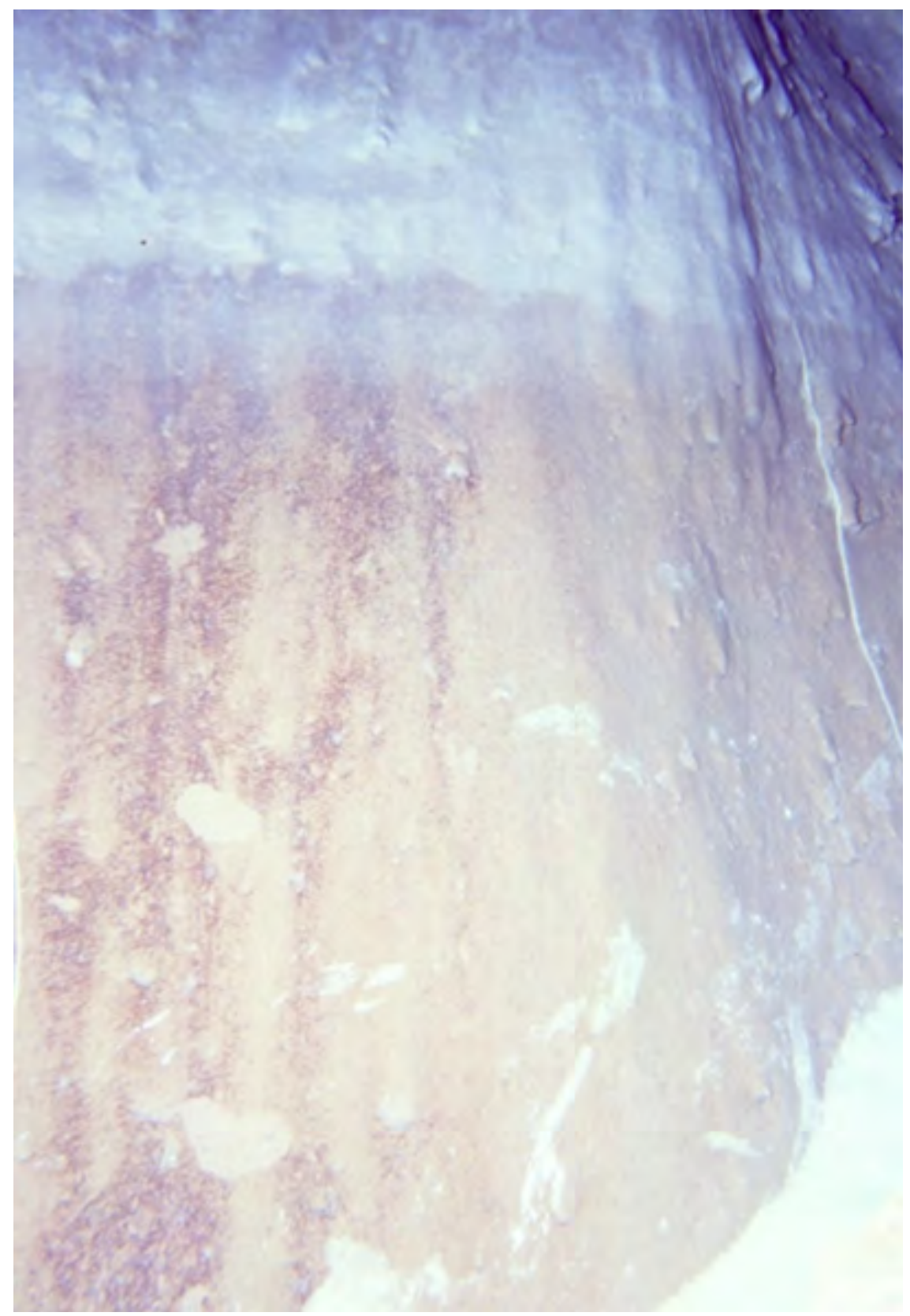

Figure 24. West wall in Browns Room, Devils Hole, Death Valley National Park, Nevada. This image of the wall is about 5 feet (1.5 meters) below the water surface. The reason for the discoloration beginning at about 3 feet (1 meter) below the water surface is unknown; perhaps it marks a former lower water level. Photograph by R.J. Hoffman, U.S. Geological Survey, 1986 (https://www.sciencebase.gov/catalog/item/580a4329e4b0f497e790645d). 


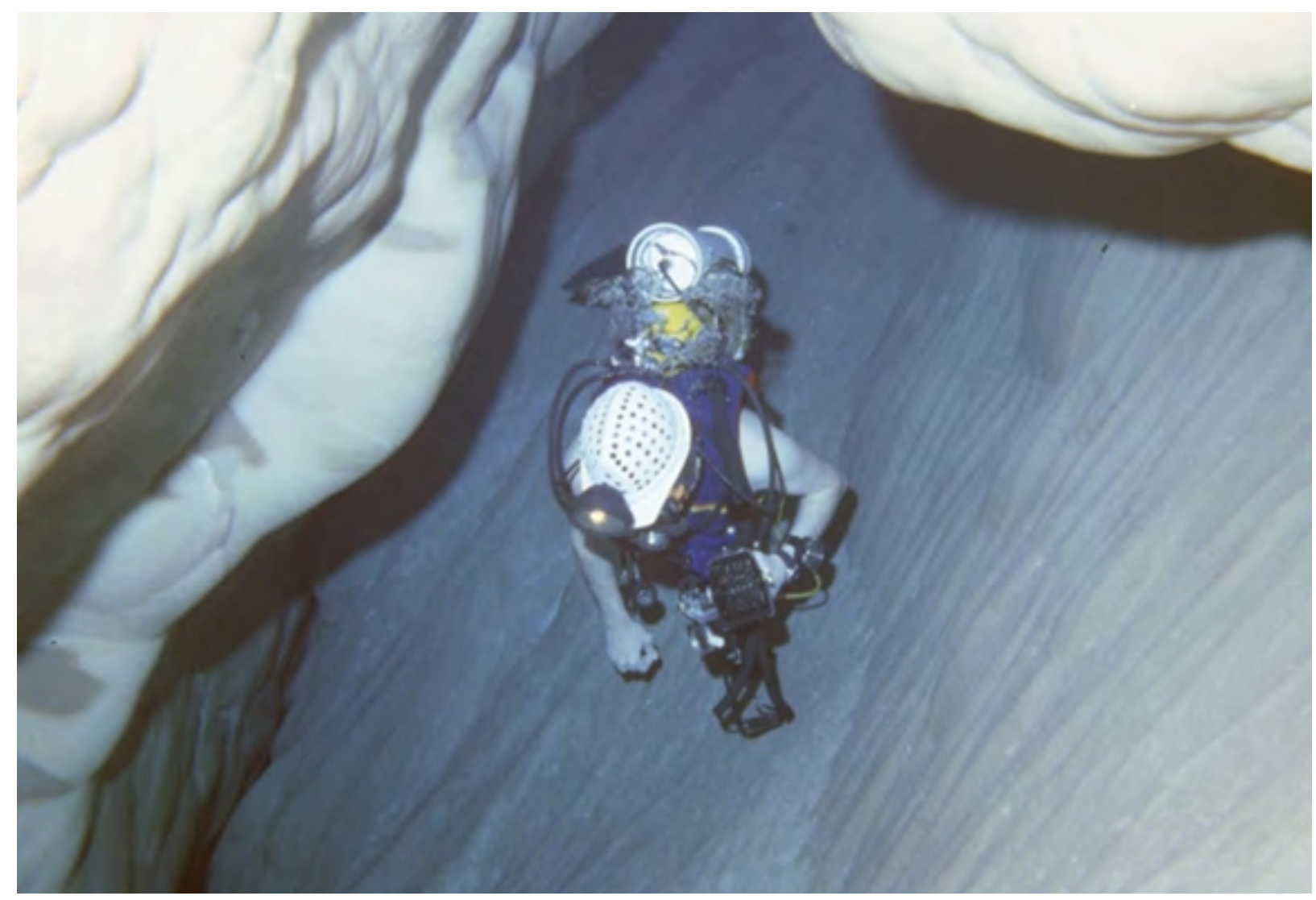

Figure 25. U.S. Geological Survey research diver in the pool of Browns Room, Devils Hole, Death Valley National Park, Nevada. The research diver is about 10 feet (3 meters) below the water surface (near $\mathrm{H}$ in fig. 4), and nearly horizontal to the water surface, in the pool of Browns Room after departing Millers Chamber (I in fig. 4). Note the high clarity of water and "cleanliness" of mammillary calcite owing to the lack of fluvial-sediment input. Photograph by R.J. Hoffman, U.S. Geological Survey, 1986 (https://www.sciencebase.gov/catalog/item/580a447fe4b0f497e79064c6). 


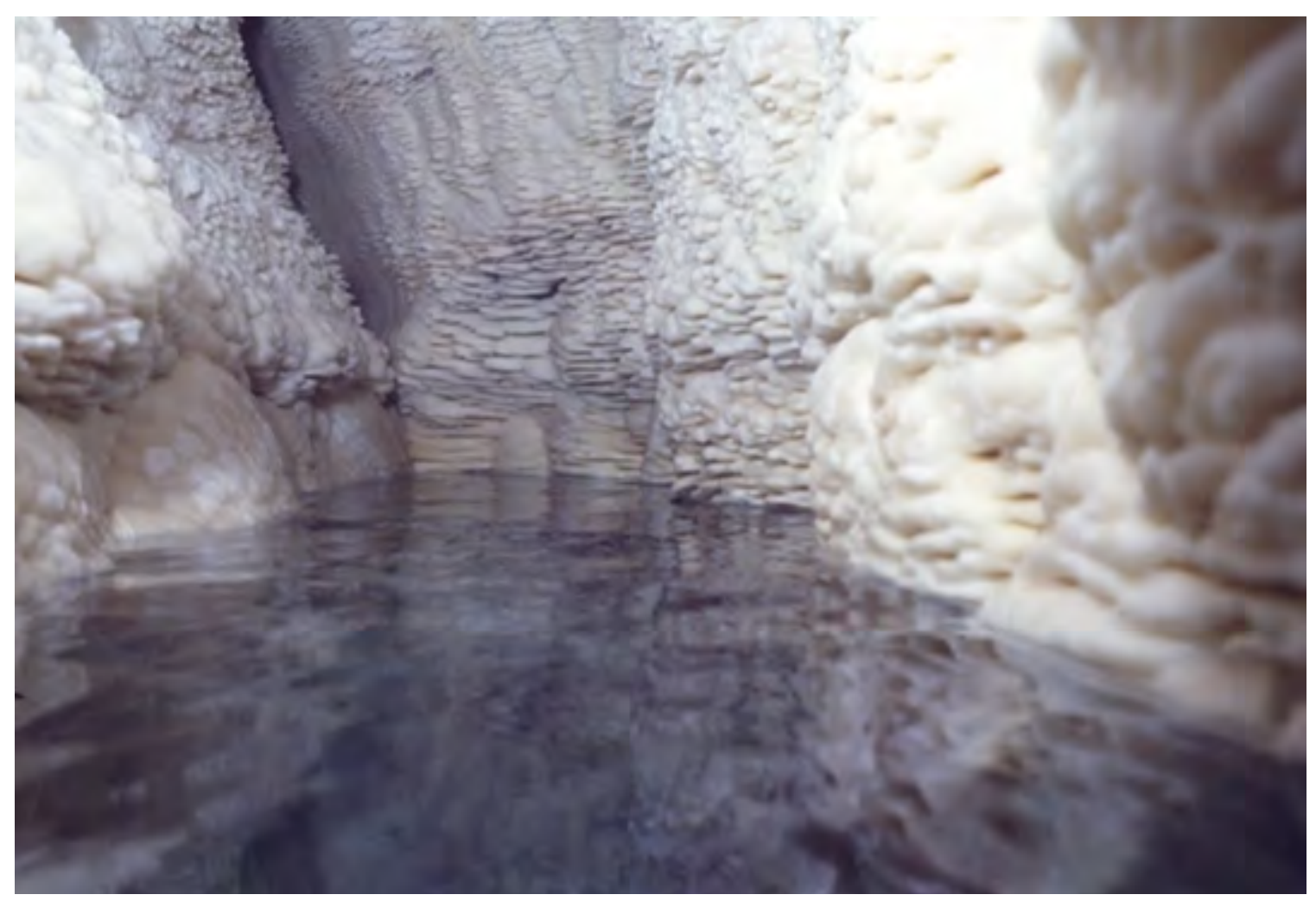

Figure 26. Water surface of Leinhaupel's Pool, Devils Hole, Death Valley National Park, Nevada. Leinhaupel's Pool (below $\mathrm{J}$ in fig. 4) is several meters to the northeast of the pool in Browns Room. For all practical purposes, this is the furthest lateral (north-south) extent of Browns Room. Note folia and popcorn above the water surface. Wall-to-wall width in foreground is about 3 feet (1 meter). Photograph by R.J. Hoffman, U.S. Geological Survey, 1986 (https://www.sciencebase.gov/catalog/item/580a4829e4b0f497e7906655). 


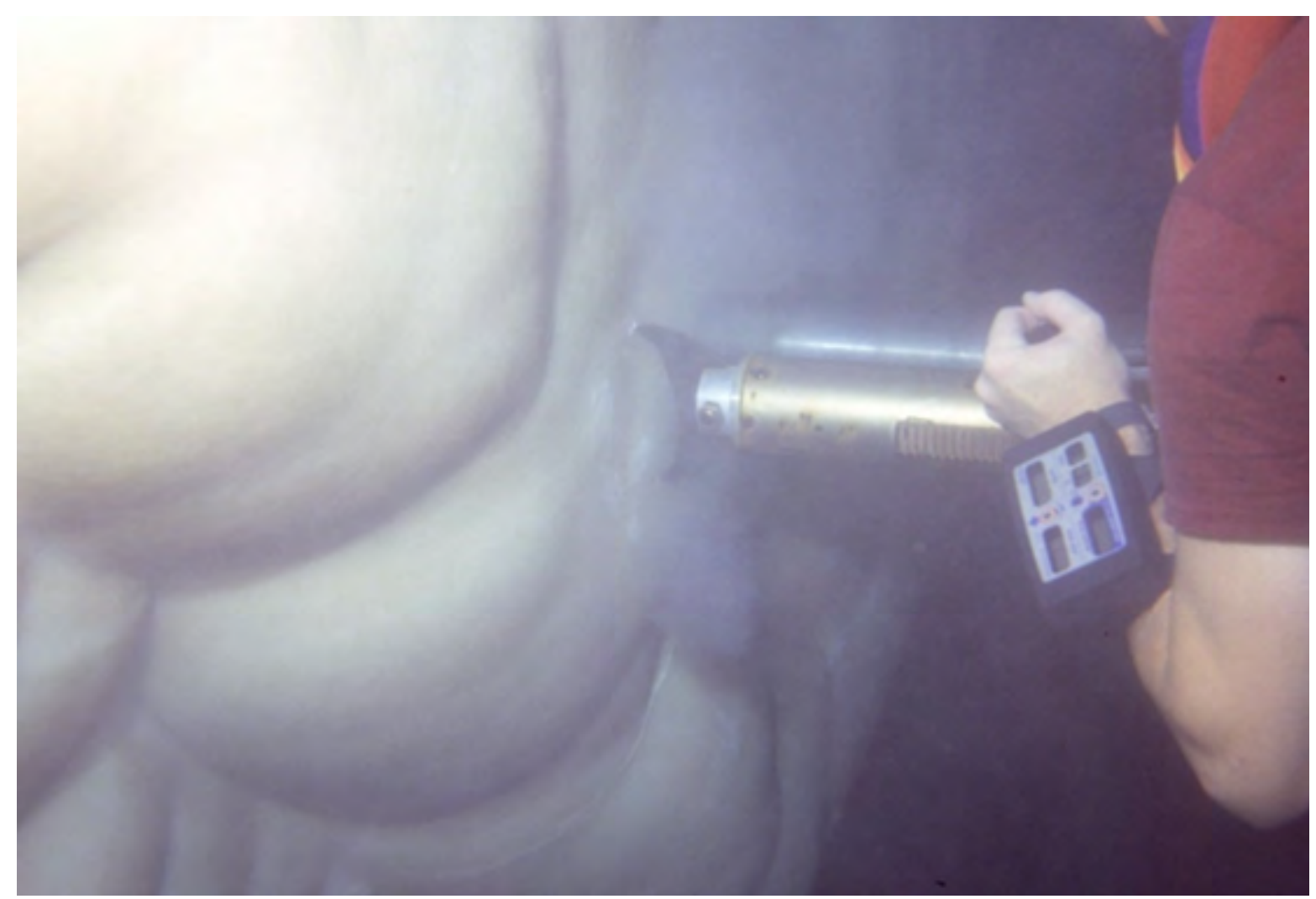

Figure 27. U.S. Geological Survey research diver coring in the main chamber, Devils Hole, Death Valley National Park, Nevada. The coring in mammillary calcite on the hanging wall in the main chamber of Devils Hole (near $\mathrm{D}$ in fig. 4) occurred during 1987 (figs. 27-31). Depth is about 100 feet (30 meters) below the water surface. Cloudiness of water is due to cuttings in suspension. Photograph by R.J. Hoffman, U.S. Geological Survey, 1987 (https://www.sciencebase.gov/catalog/item/580a49a6e4b0f497e7906670). 


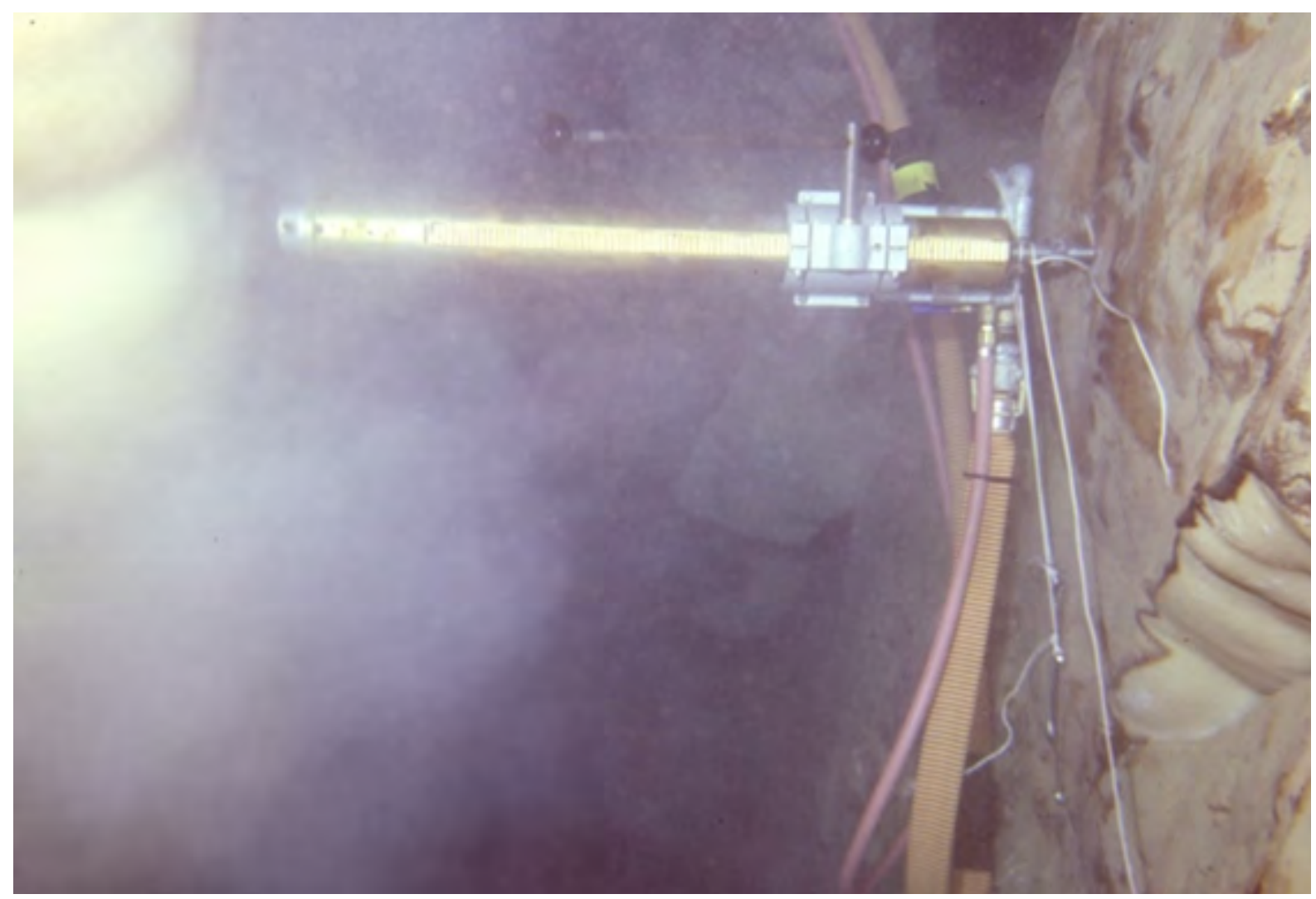

Figure 28. Coring apparatus, Devils Hole, Death Valley National Park, Nevada. This coring apparatus is wedged between the hanging wall (on the left) and the footwall (on the right) in a fissure of Devils Hole that is about 6 -feet (1.8-meters) wide. The apparatus is manually operated. Note accumulated fine-grained sediment incorporated into precipitated calcite on the exposed up-facing surface to the right in the figure. Photograph by R.J. Hoffman, U.S. Geological Survey, 1987 (https://www.sciencebase.gov/catalog/item/580a4febe4b0f497e79066ee). 


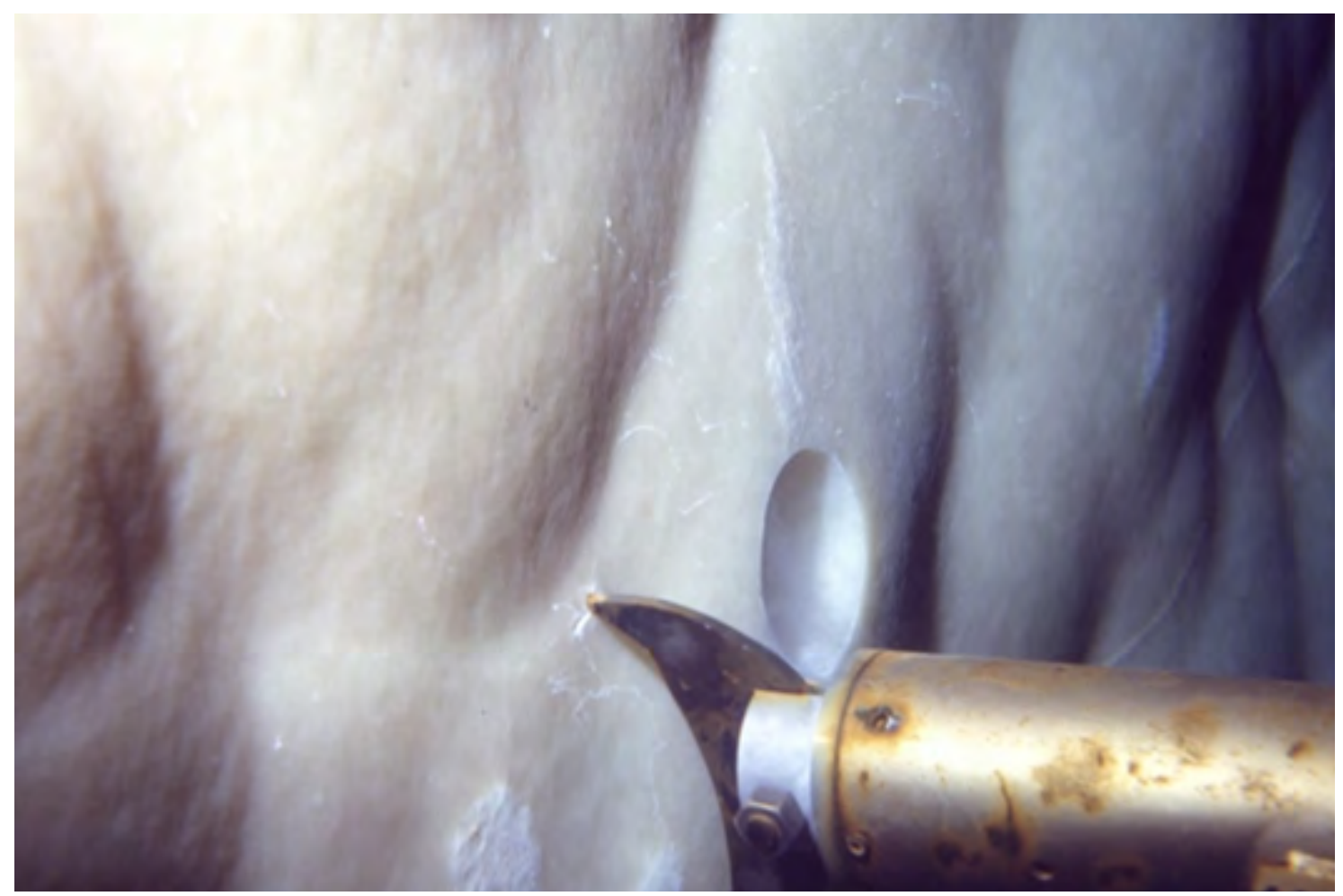

Figure 29. A 4-inch-diameter core hole, Devils Hole, Death Valley National Park, Nevada. The 4-inch (10-centimeter)-diameter core hole of $\mathrm{DH}-11$ in vein calcite on the hanging wall is about 100 feet (30 meters) below the water surface in Devils Hole. Note that there is little to no accumulation of sediment on, and thus little to no incorporation of sediment into, this overhanging surface. Photograph by R.J. Hoffman, U.S. Geological Survey, 1987 (https://www.sciencebase.gov/catalog/item/580a58fce4b0f497e7906aee). 


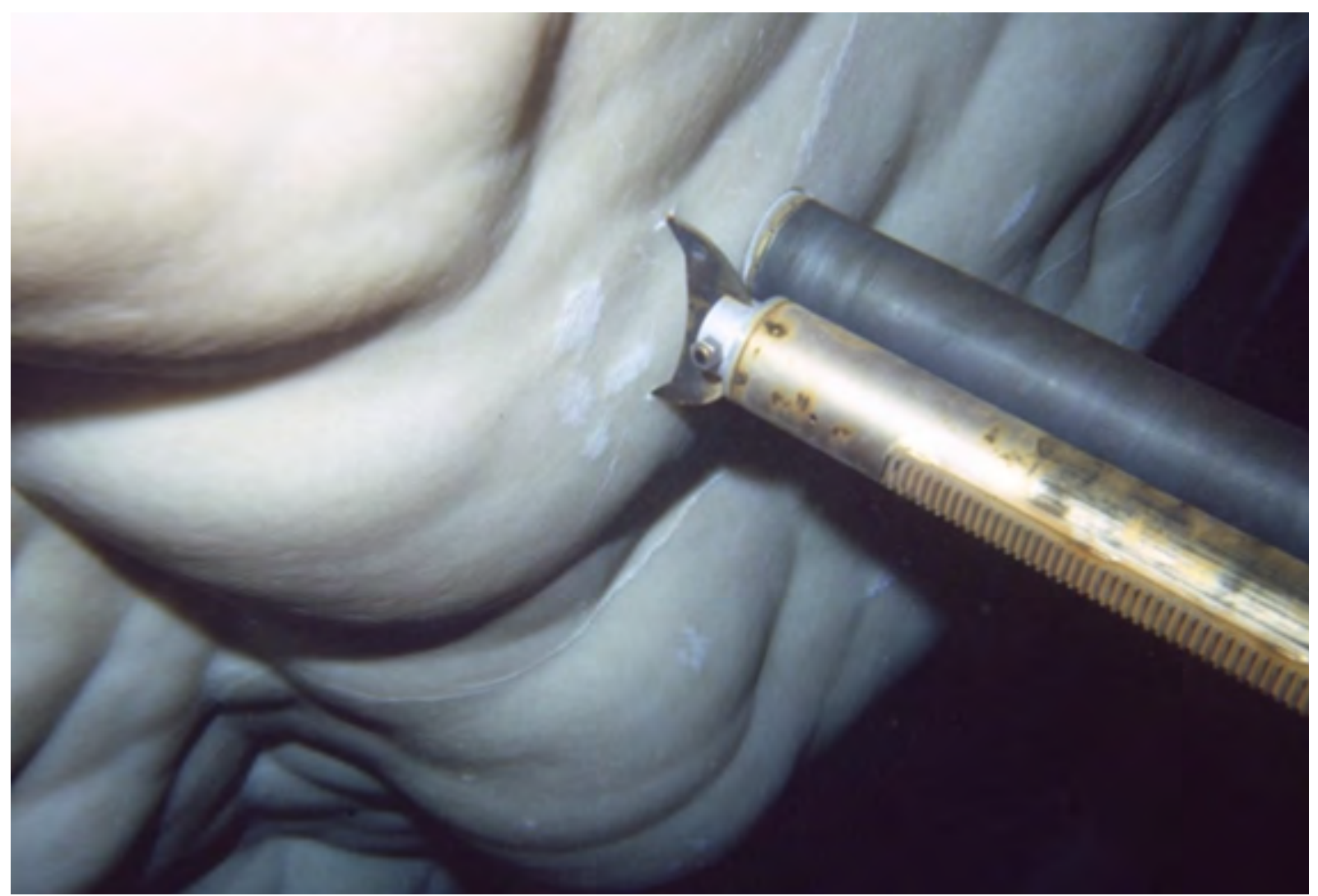

Figure 30. Setup used to obtain mammillary calcite core, Devils Hole, Death Valley National Park, Nevada. This setup was used to obtain mammillary calcite core DH-11 from the hanging wall in Devils Hole, about 100 feet (30 meters) below the water surface. The gold-colored column with rack and steel claw supports the air motor and a 4-inch (10-centimeter)-diameter core barrel. The undulating surface of the mammillary calcite mimics the morphology of the underlying bedrock. Note that there is little to no accumulation of sediment on overhanging surfaces. Photograph by R.J. Hoffman, U.S. Geological Survey, 1987 (https://www.sciencebase.gov/catalog/item/580a5a57e4b0f497e7906b1e). 


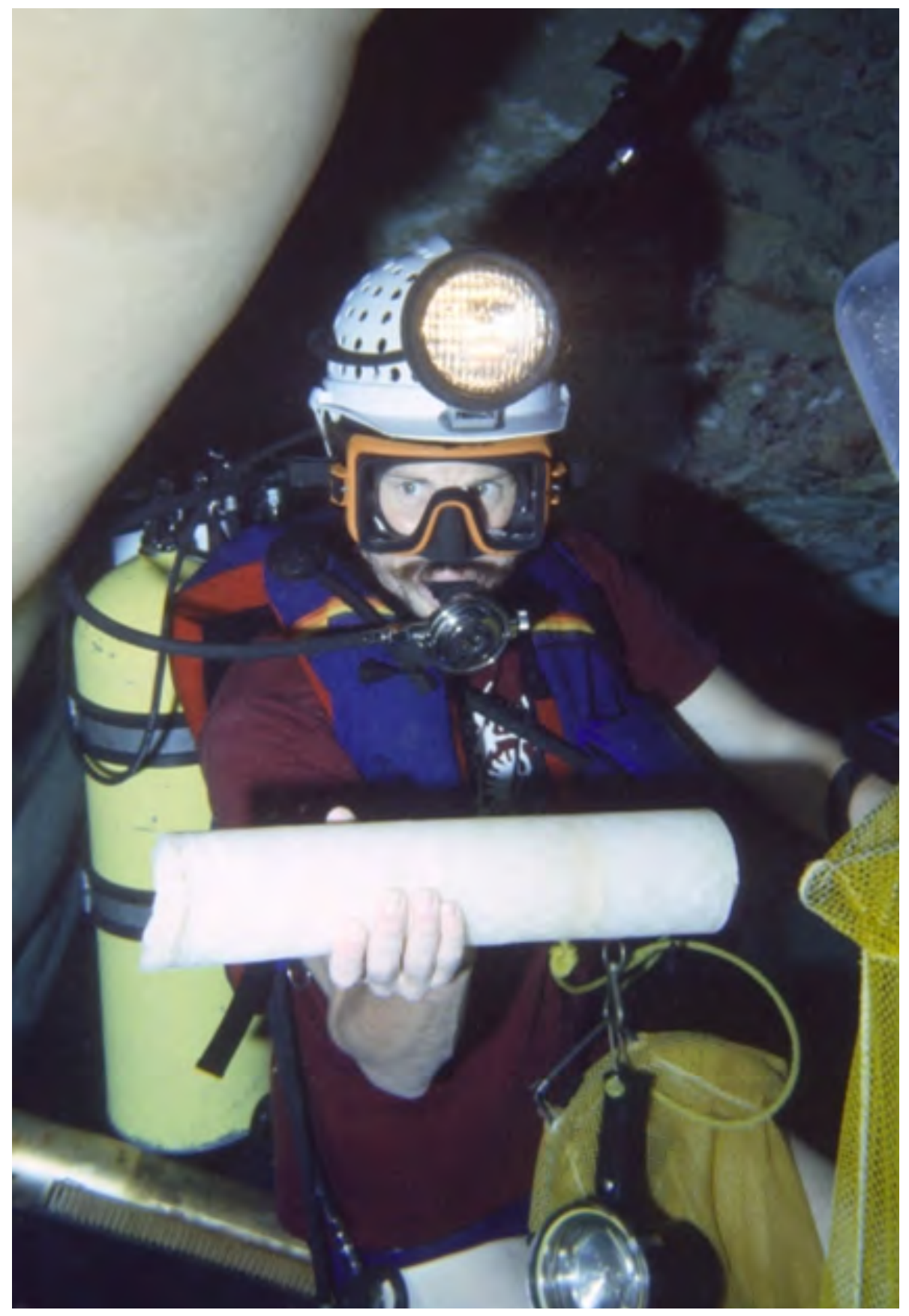

Figure 31. U.S. Geological Survey research diver holding a core of mammillary calcite, Devils Hole, Death Valley National Park, Nevada. The research diver holds a 16.5-inch (42-centimeter)-long core of mammillary calcite (DH-11) immediately after removal from the hanging wall on June 24,1987 . DH-11 yielded a remarkable climatic record (Winograd and others, 1992). Coring rack is visible below scuba tank. Photograph by R.J. Hoffman, U.S. Geological Survey, 1987 (https://www.sciencebase.gov/catalog/item/58013596e4b0824b2d18bdbd). 


\section{$\frac{\mathbb{2}}{3}$}

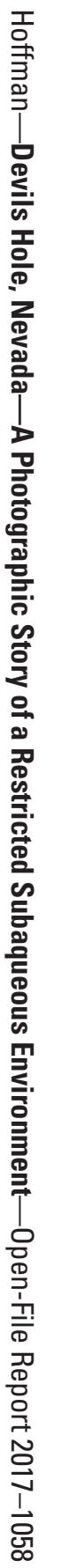

